\title{
Cobalt-Based Metal-Organic Cages for Visible-Light-Driven Water Oxidation
}

Zi-Ye Chen, ${ }^{a}$ Zi-Hao Long, ${ }^{a}$ Xue-Zhi Wang, ${ }^{a}$ Jie-Yi Zhou, ${ }^{a}$ Xu-Sheng Wang,,${ }^{a, b, *}$

Xiao-Ping Zhou, a, ${ }^{*}$ and Dan $\mathrm{Li}^{\mathrm{a}}$

a. College of Chemistry and Materials Science, Guangdong Provincial Key Laboratory

of Functional Supramolecular Coordination Materials and Applications, Jinan

University, Guangzhou, Guangdong 510632, P. R. China

${ }^{\mathrm{b}}$ International Center for Materials Nanoarchitectonics (WPI-MANA), National

Institute for Materials Science (NIMS), 1-1 Namiki, Tsukuba, Ibaraki 305-0044,

Japan

E-mail: xswang@jnu.edu.cn; zhouxp@jnu.edu.cn 


\section{Materials and Characterizations}

Starting materials, reagents, and solvents were purchased from commercial sources (Alfa Aesar, J\&K, Sigma and Aldrich) and used without further purification. Powder X-ray diffraction (PXRD) patterns of the bulk samples were measured on a Rigaku Ultima IV X-ray Diffractometer $(\mathrm{Cu} \mathrm{K} \alpha, \lambda=1.5418 \AA)$. FT-IR spectra were measured using a Nicolet Avatar 360 FT-IR spectrophotometer. Samples were dried and compressed to a plate with $\mathrm{KBr}$ for measurement. Scanning electron microscope images were obtained on a JSM-6360LA scanning electron microscope. The gas products of photo-induced oxygen evolution were analyzed by GC9790 II gas chromatography referencing against standard gas with a known concentration of oxygen. The electrochemical measurements were recorded on the CHI760E electrochemical workstation with a standard three-electrode system with the carbon paper electrode as the working electrode, platinum wire as the counter electrode and the saturated calomel electrode as a reference electrode. Isotope-labeling experiment was carried out in Agilent 5977B gas chromatography mass spectrometry. 


\section{The detailed structural information of MOC-2, 3, and 4}

We also synthesized an 8-nucleus cubic cage, MOC-2, formulated as $\left[\mathrm{Co}_{8} \mathrm{~L}_{6}\left(\mathrm{H}_{2} \mathrm{O}\right)_{6}\right] \cdot\left(\mathrm{BF}_{4}^{-}\right)_{6}, \quad\left(\mathrm{H}_{2} \mathrm{~L} 2 \quad=\quad\right.$ 1,3-bis$[(5-m e t h y l-1 \mathrm{H}-$-imidazol-4yl)methyleneaminomethyl]benzene. Different from MOC-1, MOC-2 is an 8-nucleus cubic cage, while six L2 and six $\mathrm{H}_{2} \mathrm{O}$ bridge two octahedral $\mathrm{Co}(\mathrm{III})$ and six distorted square pyramidal Co(II). Similar 8-nucleus cubic cages, MOC-3 and MOC-4 were also obtained, formulated as $\left[\mathrm{Co}_{8} \mathrm{~L}_{6}{ }_{6}\left(\mathrm{NO}_{3}\right)_{6}\right], \quad\left(\mathrm{H}_{2} \mathrm{~L} 3=1,3-\right.$ bis $[(1 \mathrm{H}$-imidazol-4yl)methyleneaminomethyl]benzene $)$ and $\left[\left(\mathrm{Co}^{\mathrm{III}} \mathrm{Co}_{4}{ }_{4} \mathrm{~L}_{12} \mathrm{Br}_{4}\right)\right] \cdot\left(\mathrm{Br}^{-}\right)_{3} \cdot\left(\mathrm{NO}_{3}^{-}\right),\left(\mathrm{H}_{2} \mathrm{~L} 4=\right.$ N-((5-methyl-1H-imidazol-4-yl)methylene)(4-methylphenyl)-methanamine), respectively. MOC-3 and MOC-4 were also 8-nucleus cubic cages, but the coordination environment of metals was different from MOC-2. MOC-3 did not have coordinate water, six $\mathrm{L} 3$ and six $\mathrm{NO}_{3}{ }^{-}$bridge two octahedral $\mathrm{Co}(\mathrm{III})$ and six distorted square pyramidal $\mathrm{Co}(\mathrm{II})$. Twelve $\mathrm{L} 4$ and four $\mathrm{Br}^{-}$anions bridge four octahedral $\mathrm{Co}(\mathrm{III})$, four tetrahedral $\mathrm{Co}(\mathrm{II})$ to construct MOC-4, which also did not have coordinate water. The coordination environment of Co centers in MOC-2, MOC-3, and MOC-4 can also be found in Figure 1 and Figure S2-4.

All of the obtained crystals were investigated by SEM, PXRD and IR spectroscopy (Figure S7-12, S14-16). All PXRD patterns of the as-synthesized MOCs were matched well with the simulated one, as well as with previous reports, which indicated the high purity of the obtained products. Furthermore, FT-IR spectra of MOC-2, MOC-3, and MOC-4 with obvious $\mathrm{C}=\mathrm{N}$ specific absorbance bands at around $1620 \mathrm{~cm}^{-1}$ suggested the L1 was in situ generated. 


\section{TOF calculation}

\subsection{TOF calculation under photo-induced conditions}

To calculate the per-active site turnover frequency, we have used formula as following:

$$
\mathrm{TOF}=\frac{\mathrm{n}\left(\mathrm{O}_{2}\right)}{\mathrm{mt}}
$$

Where $\mathrm{n}\left(\mathrm{O}_{2}\right)$ is the mole number of the produced oxygen, $\mathrm{m}$ is the mole number of active Co sites, and $\mathrm{t}$ is the reaction time (s).

Table S1. Number and type of Co sites in cages.

\begin{tabular}{ccc}
\hline Catalysts & $\begin{array}{c}\text { Total number of Co sites } \\
\text { in one cage }\end{array}$ & $\begin{array}{c}\text { Total number of active Co sites } \\
\text { in one cage }\end{array}$ \\
\hline MOC-1 & $20(\mathrm{Co} 1, \mathrm{Co} 2$, and bis $(\mu$-oxo $)$ & $16(\mathrm{Co} 2$, and bis $(\mu$-oxo $)$ dicobalt $)$ \\
dicobalt $)$ & $6(\mathrm{Co} 2)$ \\
MOC-2 & $8(\mathrm{Co} 1$, and $\mathrm{Co} 2)$ & $6(\mathrm{Co} 2)$ \\
MOC-3 & $8(\mathrm{Co} 1$, and $\mathrm{Co} 2)$ & 0 \\
\hline
\end{tabular}

\# Mole number of active sites for MOC-1 $=\frac{\mathrm{m}_{\mathrm{MOC}-1}}{\mathrm{M}_{\mathrm{MOC}-1}} \times 16$

Where $\mathrm{m}_{\mathrm{MOC}-1}$ is the mass of MOC-1 on carbon paper electrode, $\mathrm{M}_{\mathrm{MOC}-1}$ is the mole mass of MOC-1, 16 is the active Co sites in one cage.

\# Mole number of active sites for MOC-2 $=\frac{\mathrm{m}_{\mathrm{MOC}-2}}{\mathrm{M}_{\mathrm{MOC}-2}} \times 6$

Where $\mathrm{m}_{\mathrm{MOC}-2}$ is the mass of MOC-2 on carbon paper electrode, $\mathrm{M}_{\mathrm{MOC}-2}$ is the mole mass of MOC-2, 6 is the active Co sites in one cage.

\# Mole number of active sites for MOC-3 $=\frac{\mathrm{m}_{\mathrm{MOC}-3}}{\mathrm{M}_{\mathrm{MOC}-3}} \times 6$

Where $\mathrm{m}_{\mathrm{MOC}-3}$ is the mass of MOC-3 on carbon paper electrode, $\mathrm{M}_{\mathrm{MOC}-3}$ is the mole mass of MOC-3, 6 is the active Co sites in one cage.

\subsection{TOF calculation under electrochemical conditions}

To calculate the per-active site turnover frequency, we have used formula as following: 


$$
\mathrm{TOF}=\frac{j \mathrm{~A}}{4 \mathrm{Fm}}
$$

Where $j$ is the current density, $\mathrm{A}$ is the geometrical surface area of the electrode, 4 indicates the mole of electrons consumed for one mole of $\mathrm{O}_{2}$ evolution, $\mathrm{F}$ is Faraday's constant $\left(96485 \mathrm{~A} \cdot \mathrm{S} \cdot \mathrm{mol}^{-1}\right)$ and $\mathrm{m}$ is the mole number of active Co sites.

To compare the TOF at photo-induced and electrochemical conditions, the current densities were obtained at $1.02 \mathrm{~V}$ vs. SCE from LSV curves, which is the oxide potential of $\left[\mathrm{Ru}(\mathrm{bpy})_{3}\right]^{3+}$.

\# Mole number of active sites for MOC-1 $=\frac{\mathrm{m}_{\mathrm{MOC}-1}}{\mathrm{M}_{\mathrm{MOC}-1}} \times 16$

Where $\mathrm{m}_{\mathrm{MOC}-1}$ is the mass of MOC-1 on carbon paper electrode, $\mathrm{M}_{\mathrm{MOC}-1}$ is the mole mass of MOC-1, 16 is the active Co sites in one cage.

\# Mole number of active sites for MOC-2 $=\frac{\mathrm{m}_{\mathrm{MOC}-2}}{\mathrm{M}_{\mathrm{MOC}-2}} \times 6$

Where $\mathrm{m}_{\mathrm{MOC}-2}$ is the mass of MOC-2 on carbon paper electrode, $\mathrm{M}_{\mathrm{MOC}-2}$ is the mole mass of MOC-2, 6 is the active Co sites in one cage.

\# Mole number of active sites for MOC-3 $=\frac{\mathrm{m}_{\mathrm{MOC}-3}}{\mathrm{M}_{\mathrm{MOC}-3}} \times 6$

Where $\mathrm{m}_{\mathrm{MOC}-3}$ is the mass of MOC-3 on carbon paper electrode, $\mathrm{M}_{\mathrm{MOC}-3}$ is the mole mass of MOC-3, 6 is the active Co sites in one cage.

Table S2. TOF calculation under electrochemical condition.

\begin{tabular}{ccccc}
\hline Catalysts & $\mathrm{M}(\mathrm{g} / \mathrm{mol})$ & $\begin{array}{c}\text { Number of active } \\
\text { Co sites in one } \\
\text { cage }\end{array}$ & $\begin{array}{c}\text { Current } \\
\text { density } \\
\left(\mathrm{mA} / \mathrm{cm}^{2}\right)^{\mathrm{a}}\end{array}$ & TOF $\left(\mathrm{s}^{-1}\right)$ \\
\hline MOC-1 & 5362.71 & 16 & 3.0625 & $9.575 \times 10^{-3}$ \\
MOC-2 & 2533.25 & 6 & 0.6292 & $2.48 \times 10^{-3}$ \\
MOC-3 & 2585.49 & 6 & 0.6676 & $2.68 \times 10^{-3}$ \\
MOC-4 & 3798.37 & 0 & -- & -- \\
\hline
\end{tabular}

${ }^{a}$ The current densities was obtained at $1.02 \mathrm{~V}$ vs. SCE from LSV curves. 


\section{Supplementary figures and tables}

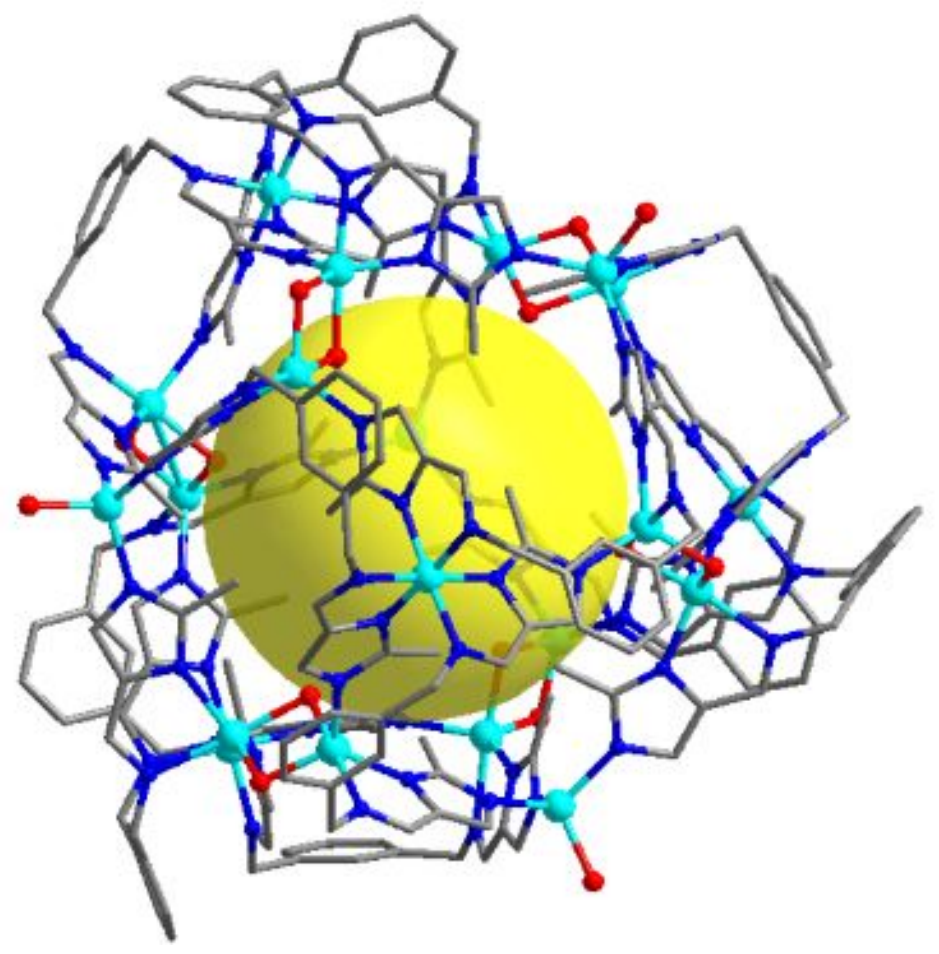

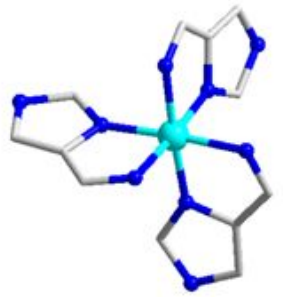

Co1

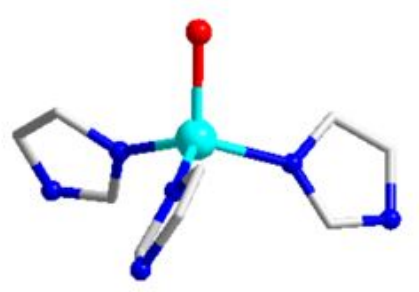

$\mathrm{Co2}$

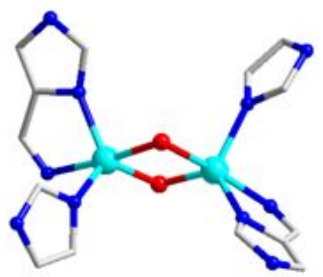

bis( $(1-0 x 0)$ dicobalt

Figure S1. The coordination environment of Co centers in MOC-1. Color codes for elements: Co turquoise, $\mathrm{N}$ blue, $\mathrm{C}$ gray, $\mathrm{O}$ red, hydrogen atoms are omitted for clarity. In one cage of MOC-1, there are $4 \mathrm{Co} 1,4 \mathrm{Co} 2$, and 6 bis( $\mu$-oxo) dicobalt. 


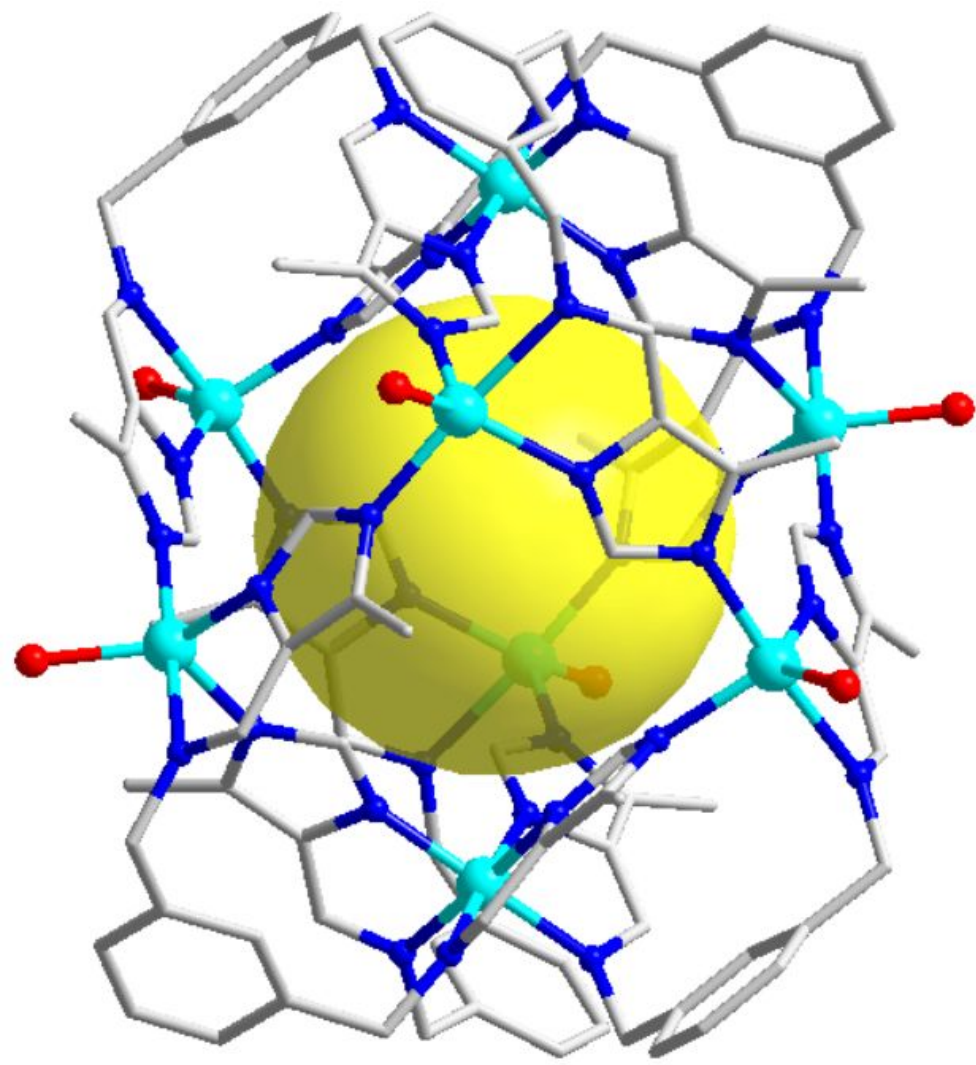

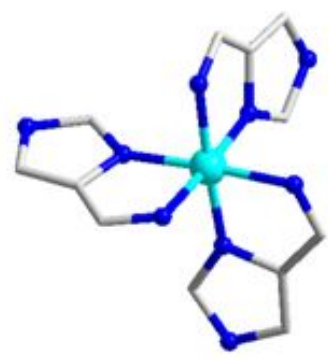

Co1

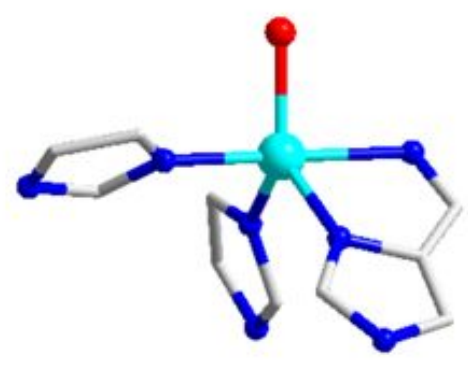

$\mathrm{Co2}$

Figure S2. The coordination environment of Co centers in MOC-2. Color codes for elements: Co turquoise, $\mathrm{N}$ blue, $\mathrm{C}$ gray, $\mathrm{O}$ red, hydrogen atoms are omitted for clarity. In one cage of MOC-2, there are $2 \mathrm{Co} 1$ and $6 \mathrm{Co} 2$. 


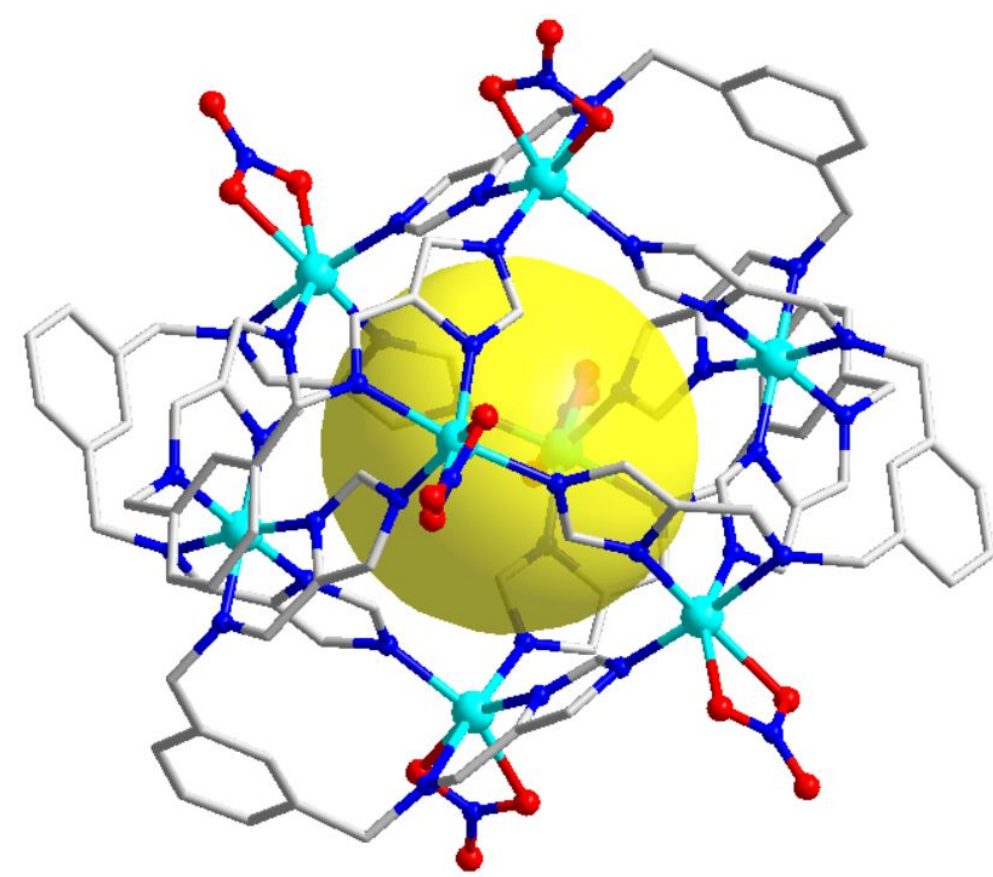

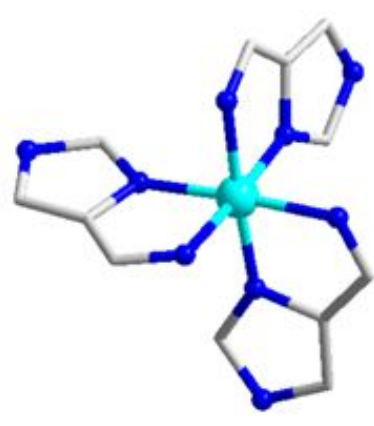

Co1

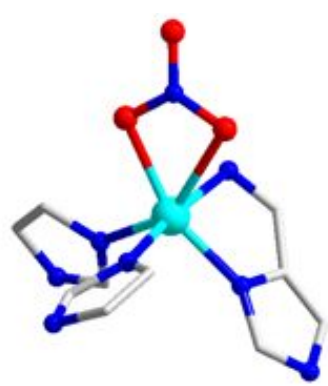

$\mathrm{Co2}$

Figure S3. The coordination environment of Co centers in MOC-3. Color codes for elements: Co turquoise, $\mathrm{N}$ blue, $\mathrm{C}$ gray, $\mathrm{O}$ red, hydrogen atoms are omitted for clarity. In one cage of MOC-3, there are $2 \mathrm{Co} 1$ and $6 \mathrm{Co} 2$. 

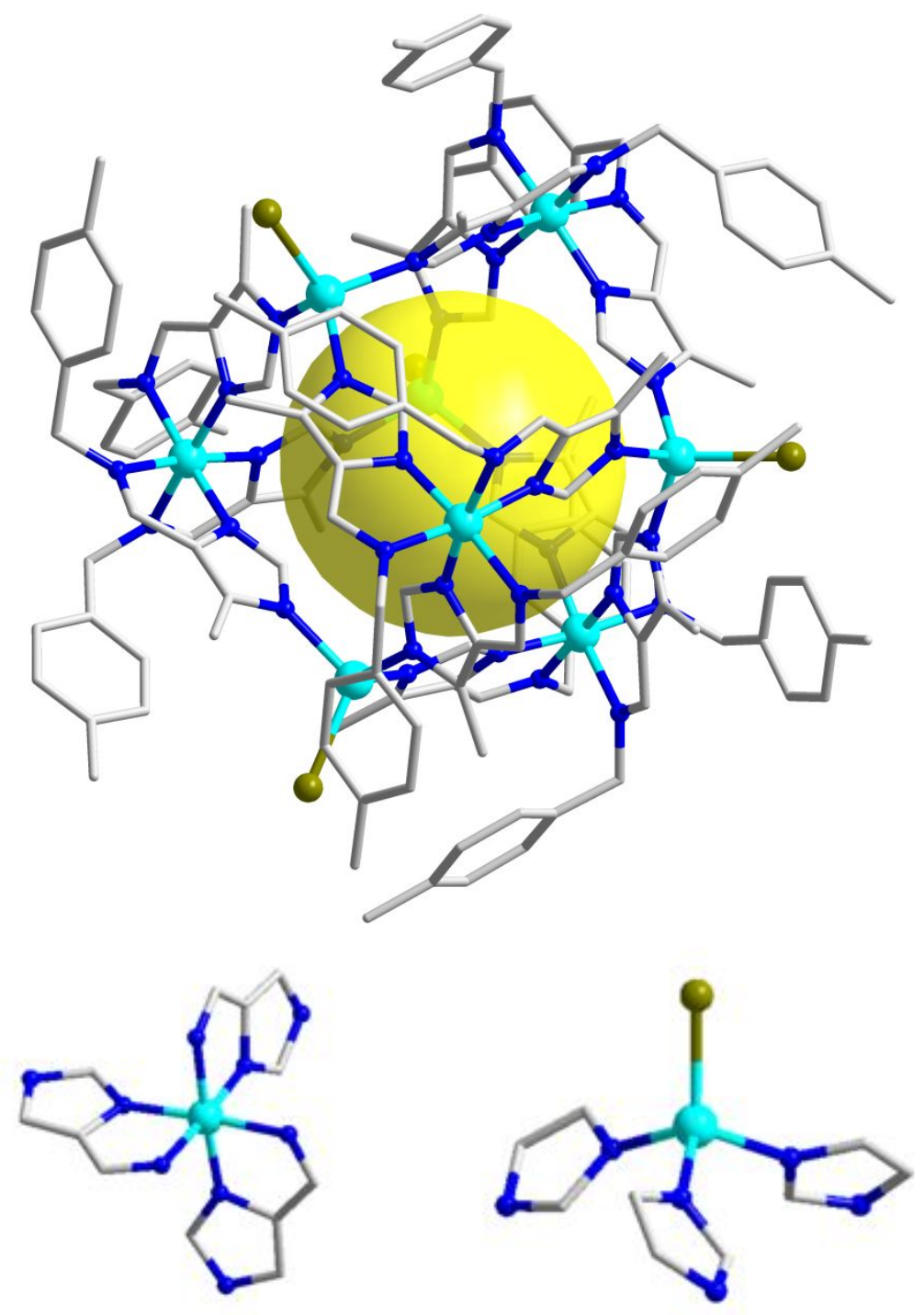

\section{Co1}

$\mathrm{Co2}$

Figure S4. The coordination environment of Co centers in MOC-4. Color codes for elements: Co turquoise, $\mathrm{N}$ blue, $\mathrm{C}$ gray, $\mathrm{O}$ red, $\mathrm{Br}$ dark yellow, hydrogen atoms are omitted for clarity. In one cage of MOC-4, there are $4 \mathrm{Co} 1$ and $4 \mathrm{Co} 2$. 


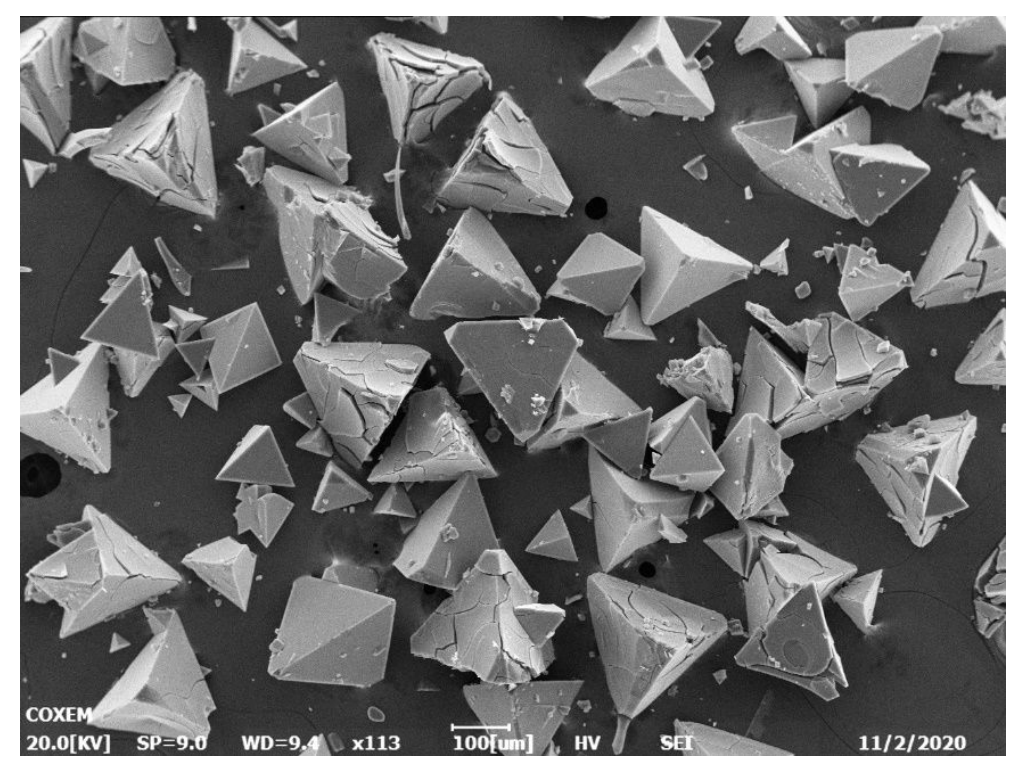

Figure S5. The SEM of MOC-1.

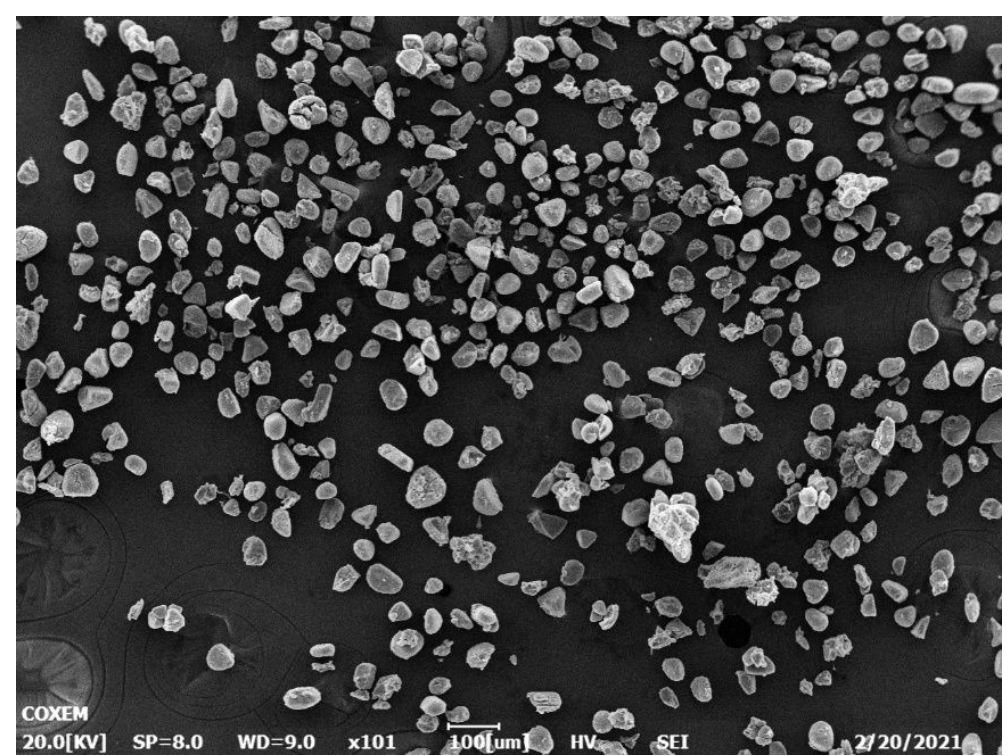

Figure S6. The SEM of MOC-1 after photo-induced water oxidation. 


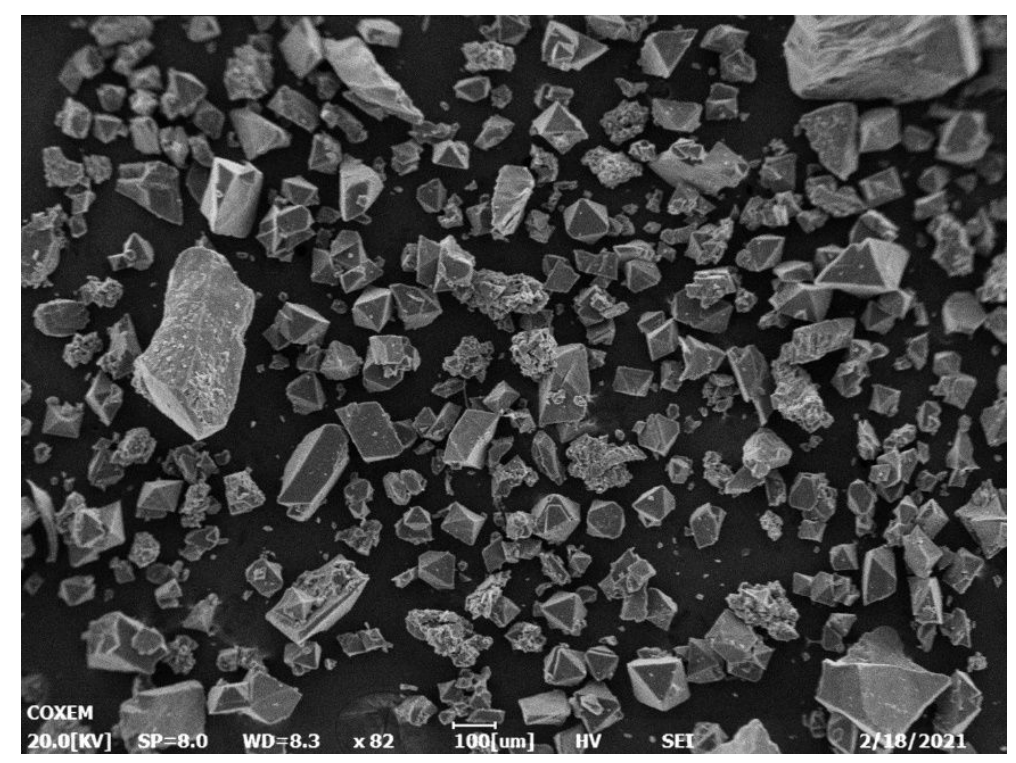

Figure S7. The SEM of MOC-2.

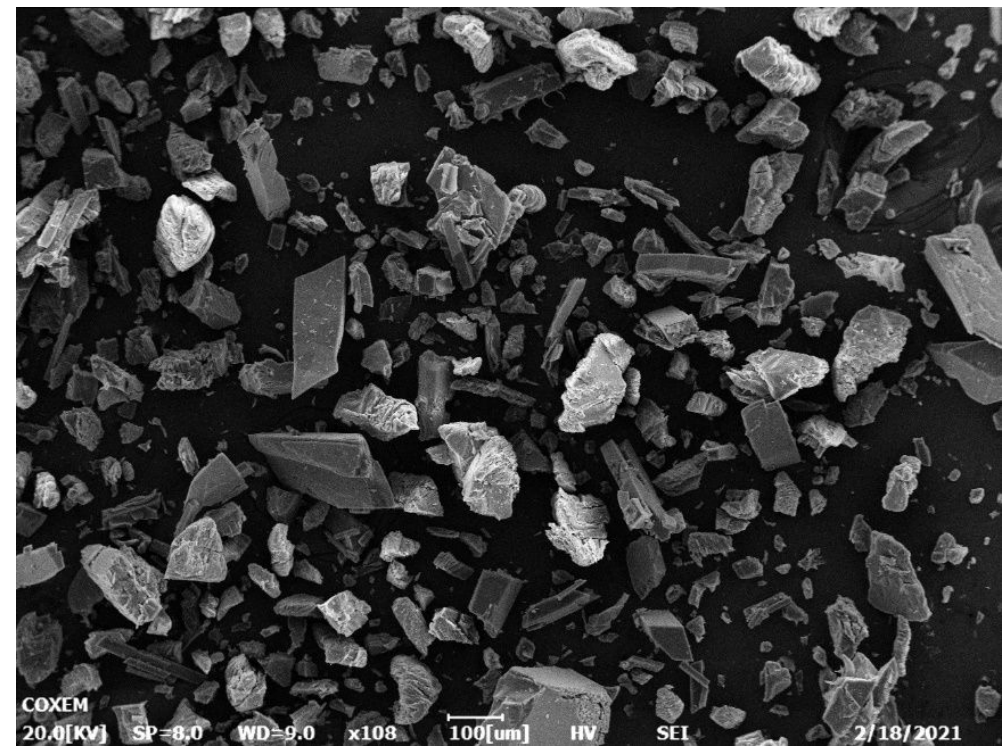

Figure S8. The SEM of MOC-3. 


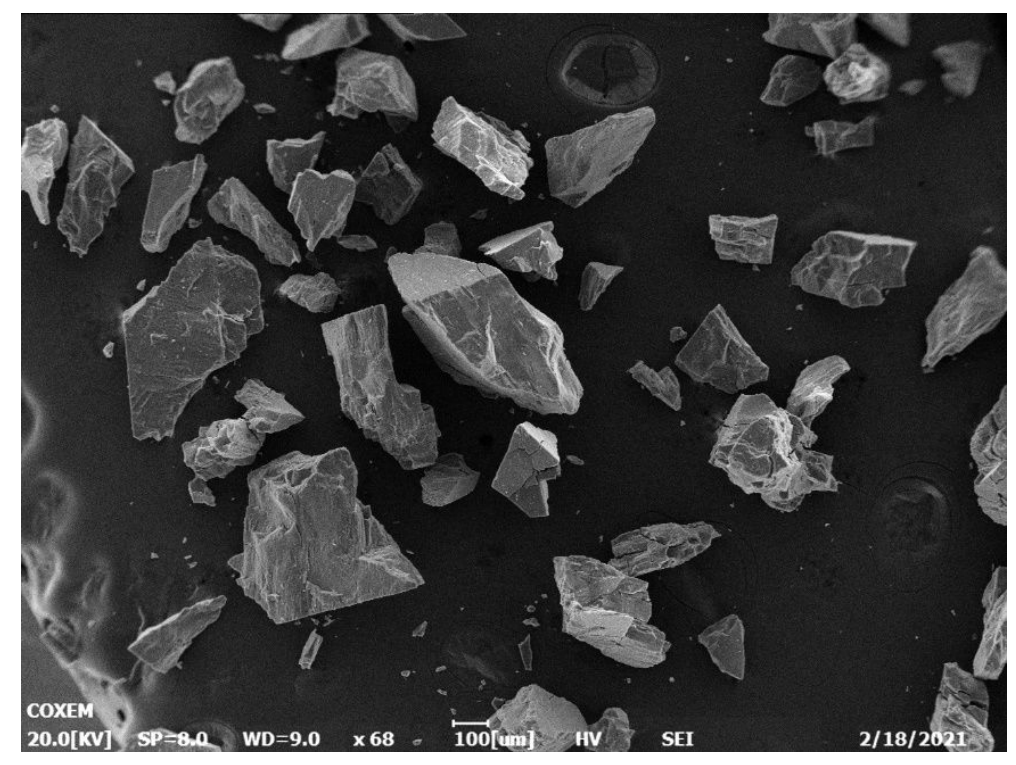

Figure S9. The SEM of MOC-4.

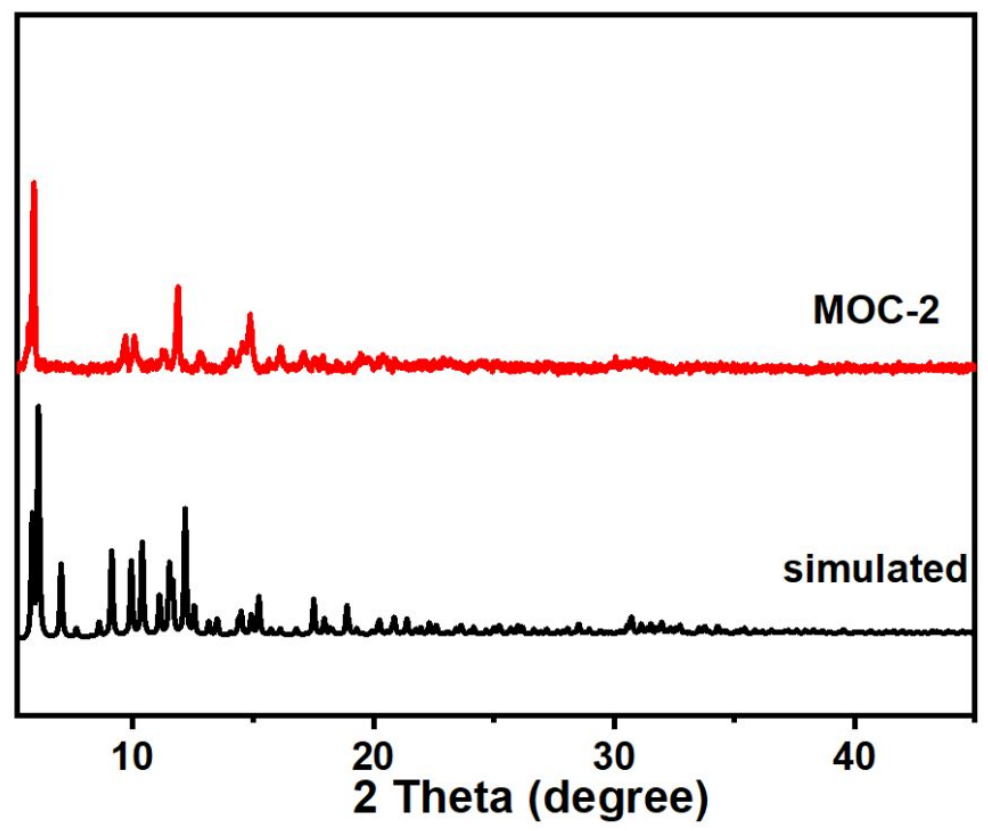

Figure S10. PXRD patterns for simulated (black line) and as-synthesized (red line) MOC-2. The differences between experimental and simulated powder patterns is attributed to the preferred orientation of desolvation effects. 


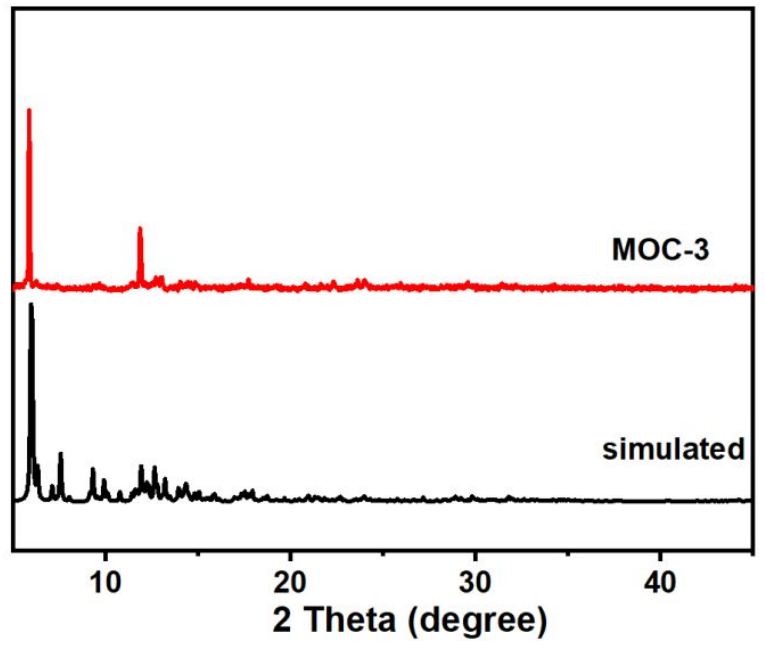

Figure S11. PXRD patterns for simulated (black line) and as-synthesized (red line) MOC-3. The differences between experimental and simulated powder patterns is attributed to the preferred orientation of desolvation effects.

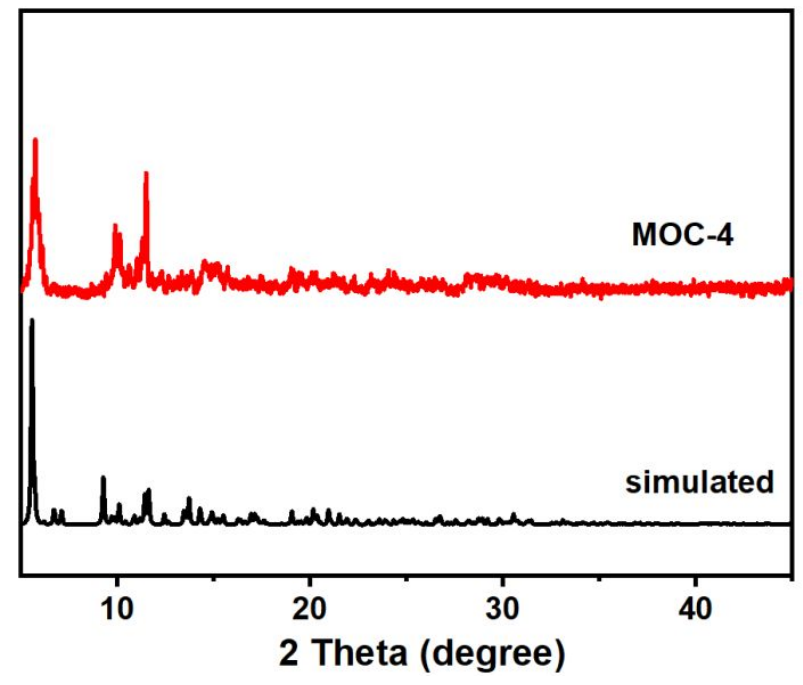

Figure S12. PXRD patterns for simulated (black line) and as-synthesized (red line) MOC-4. The differences between experimental and simulated powder patterns is attributed to the preferred orientation of desolvation effects. 


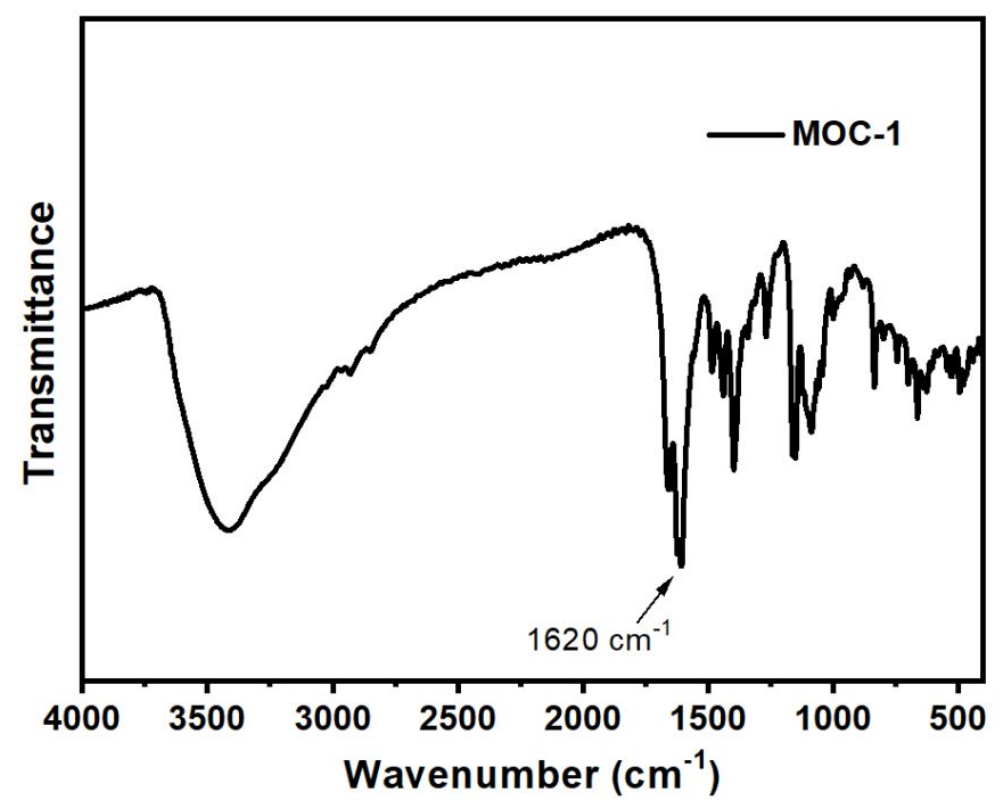

Figure S13. FT-IR spectrum of MOC-1.

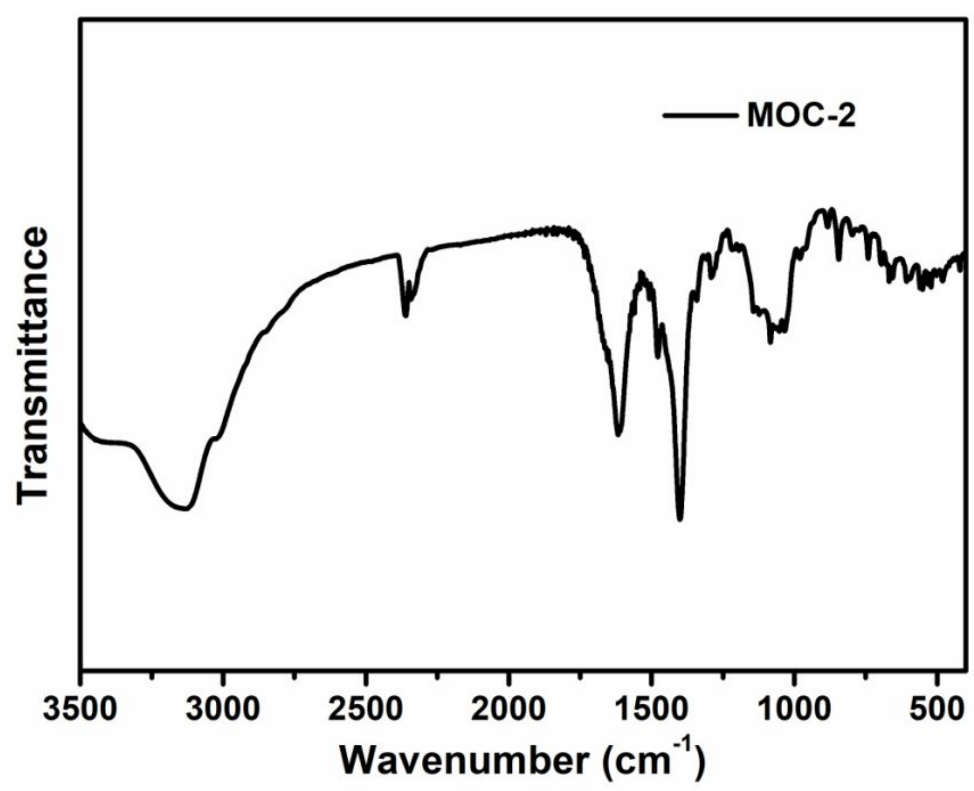

Figure S14. FT-IR spectrum of MOC-2. 


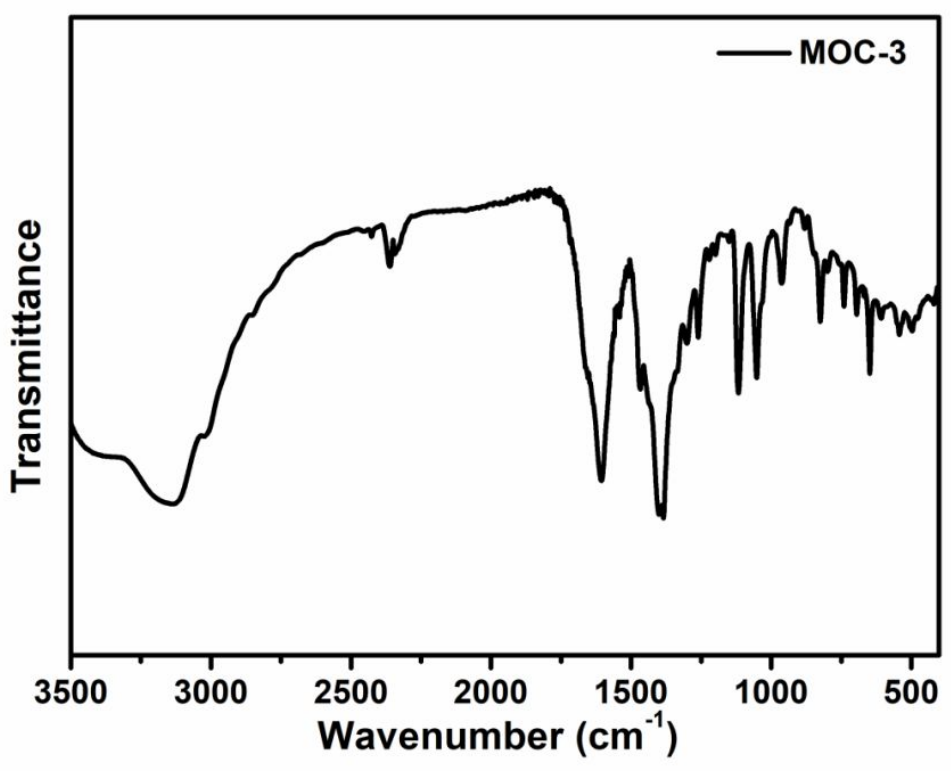

Figure S15. FT-IR spectrum of MOC-3.

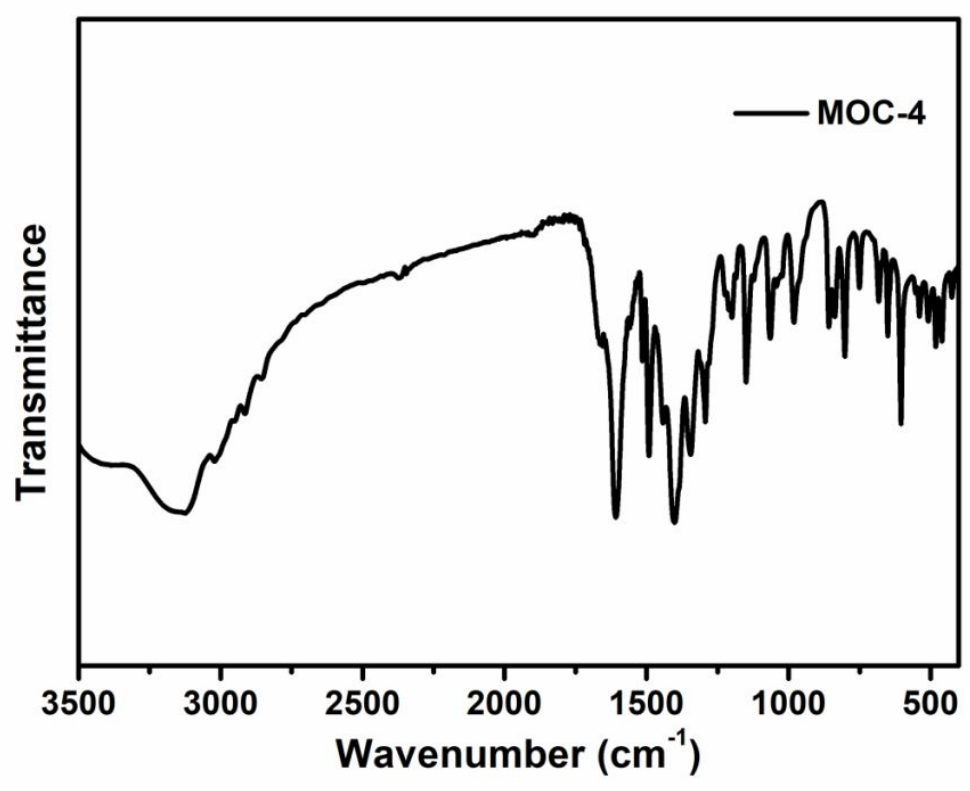

Figure S16. FT-IR spectrum of MOC-4. 


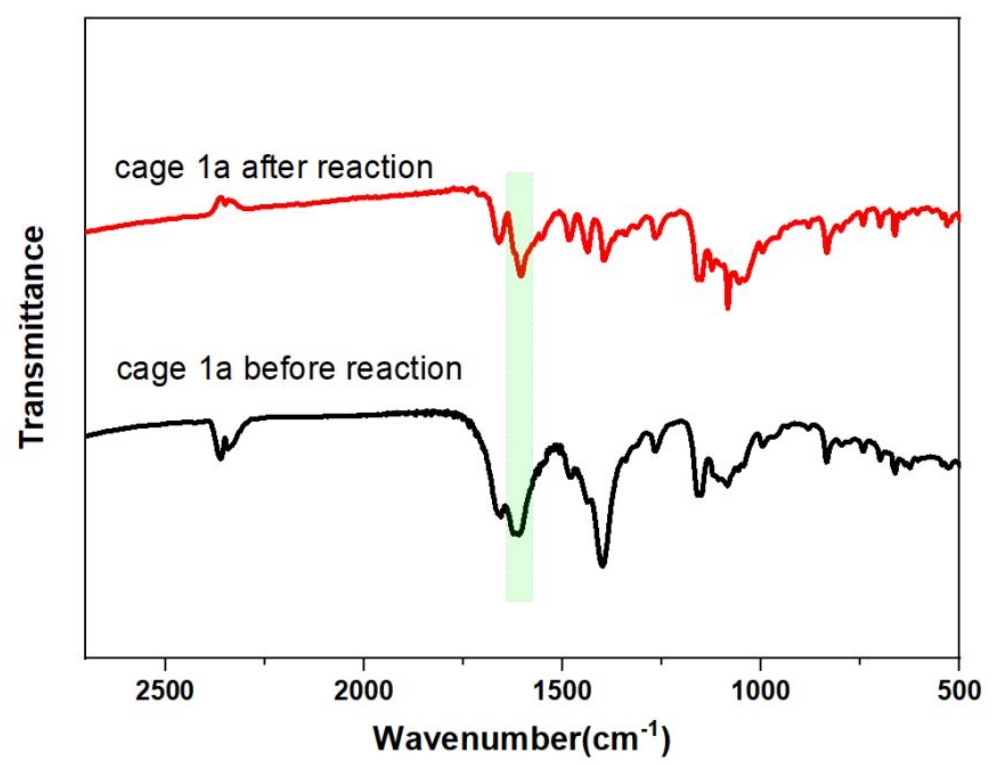

Figure S17. FT-IR spectra of MOC-1before and after catalysis.

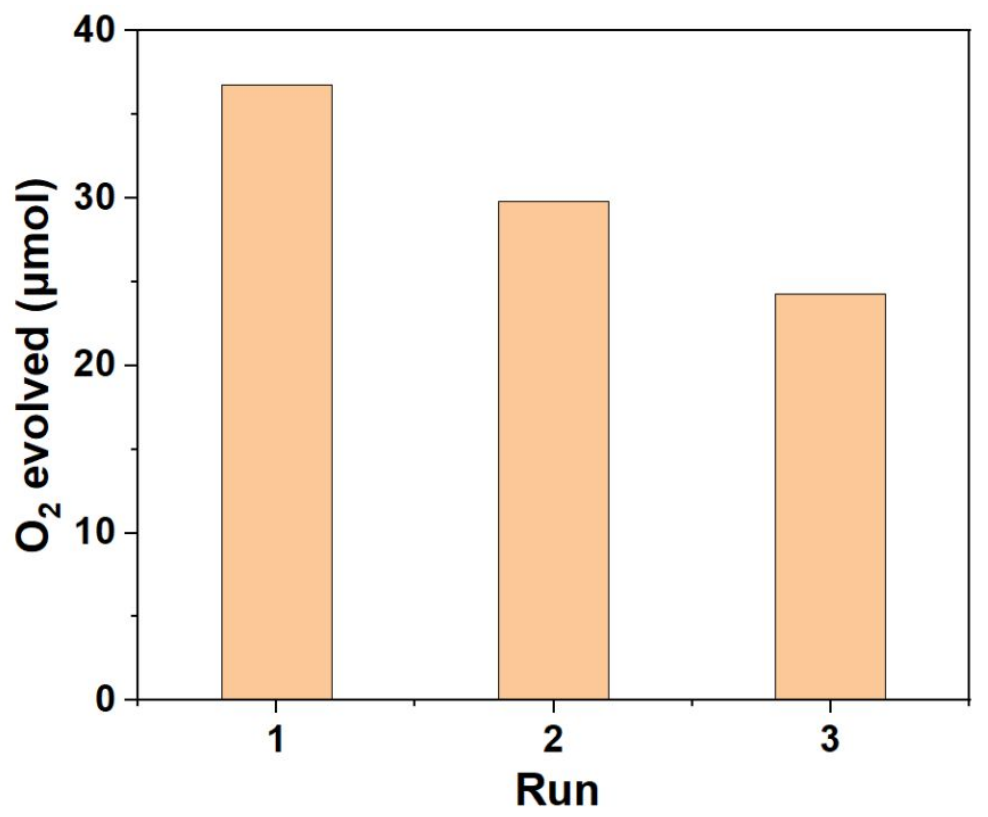

Figure S18. Recycled MOC-1 for water oxidation. Reaction conditions : photocatalysts $(2.0 \mathrm{mg}),\left[\mathrm{Ru}(\mathrm{bpy})_{3}\right] \mathrm{Cl}_{2}(50 \mu \mathrm{mol}), \mathrm{Na}_{2} \mathrm{~S}_{2} \mathrm{O}_{8}(400 \mu \mathrm{mol})$, borate buffer (10.0 mL, 0.2 M), LED light $(\lambda=470 \mathrm{~nm}), 1$ hour. 


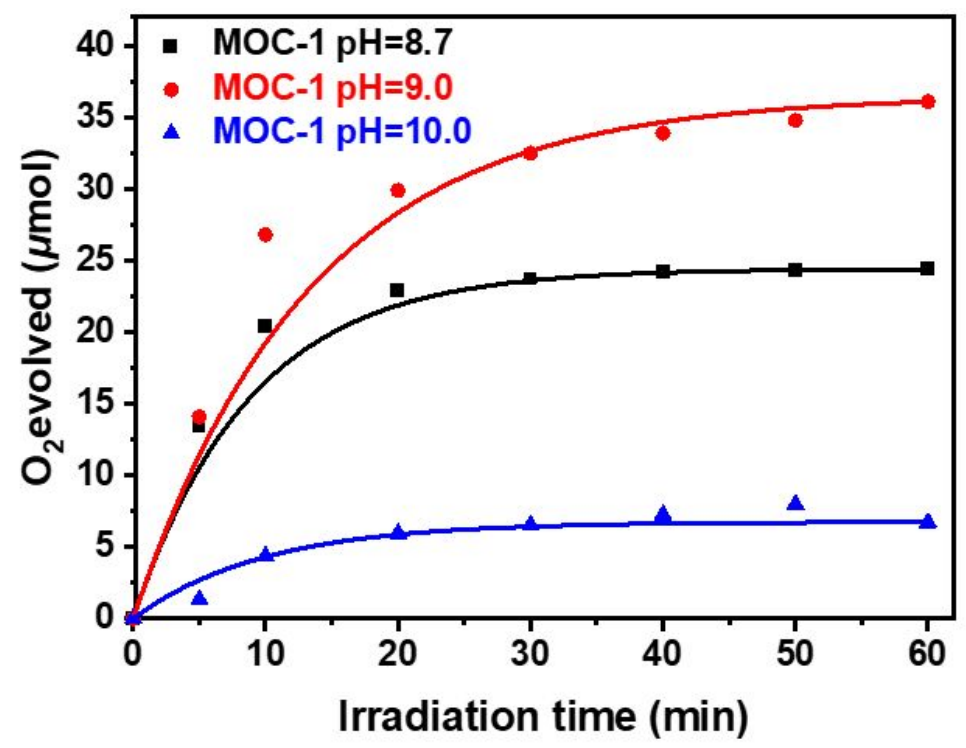

Figure S19. Time-resolved $\mathrm{O}_{2}$ evolution with MOC-1 as photocatalysts at different $\mathrm{pH}$. Reaction conditions : photocatalysts $(2.0 \mathrm{mg}),\left[\mathrm{Ru}(\mathrm{bpy})_{3}\right] \mathrm{Cl}_{2}(50 \mu \mathrm{mol}), \mathrm{Na}_{2} \mathrm{~S}_{2} \mathrm{O}_{8}(400$ $\mu \mathrm{mol})$, borate buffer $(10.0 \mathrm{~mL}, 0.2 \mathrm{M})$, LED light $(\lambda=470 \mathrm{~nm})$. 


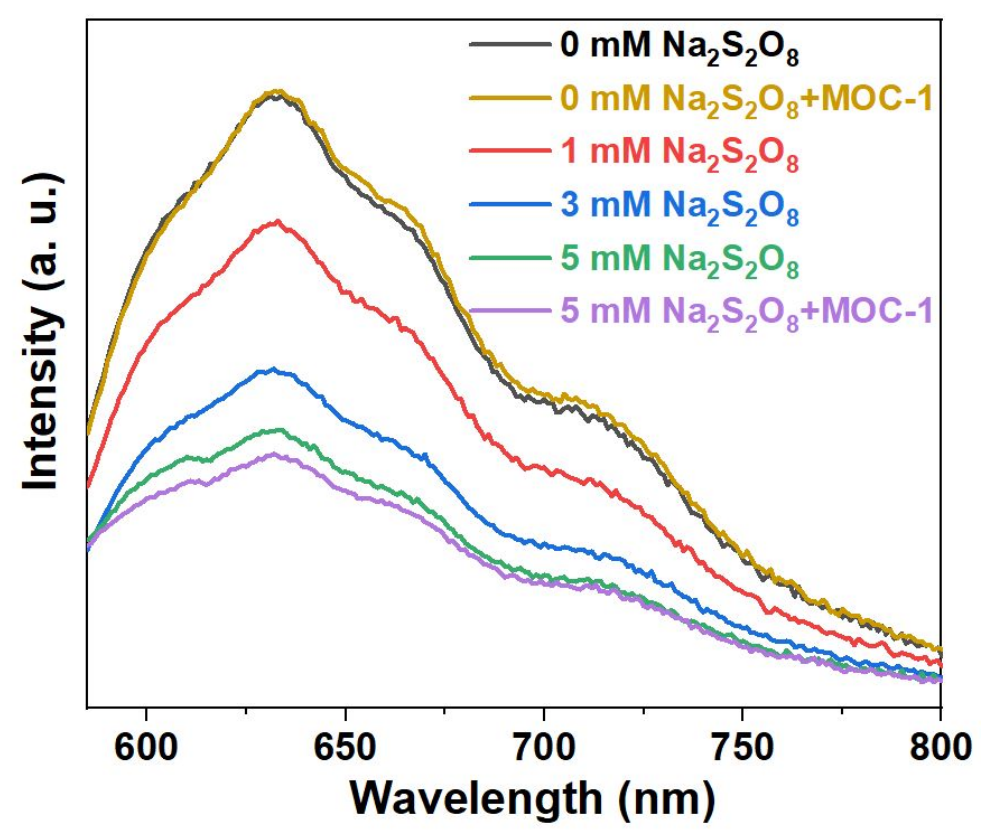

Figure S20. Steady-state luminescence spectra of $\left[\mathrm{Ru}(\mathrm{bpy})_{3}\right] \mathrm{Cl}_{2}$ in the presence and absence of $\mathrm{Na}_{2} \mathrm{~S}_{2} \mathrm{O}_{8}$ or MOC-1. Conditions: [Ru(bpy) $\left.)_{3}\right] \mathrm{Cl}_{2}(50 \mu \mathrm{mol}), \mathrm{Na}_{2} \mathrm{~S}_{2} \mathrm{O}_{8}(400$ $\mu \mathrm{mol})$, borate buffer $(2.5 \mathrm{~mL}, 0.2 \mathrm{M}$, initial $\mathrm{pH}=9.0)$, MOC-1 $(0.6 \mathrm{mg}), \lambda_{\mathrm{ex}}=560 \mathrm{~nm}$.

To study the catalytic mechanisms, steady-state luminescence spectra of homogeneous $\left[\mathrm{Ru}(\mathrm{bpy})_{3}\right] \mathrm{Cl}_{2}$ in the presence of $\mathrm{Na}_{2} \mathrm{~S}_{2} \mathrm{O}_{8}$ and MOC-1 in borate buffer solution $(\mathrm{pH}=9.0)$ were conducted. As shown in Figure 3a, the luminescence of $\left[\mathrm{Ru}(\text { bpy })_{3}\right] \mathrm{Cl}_{2}$ was efficiently quenched by $\mathrm{Na}_{2} \mathrm{~S}_{2} \mathrm{O}_{8}$ but not by MOC- 1 . These results indicate that photo-induced water oxidation in MOC-1 initiates via electron transfer from the excited $\left[\mathrm{Ru}(\mathrm{bpy})_{3}\right]^{2+*}$ to $\mathrm{Na}_{2} \mathrm{~S}_{2} \mathrm{O}_{8}$, and the oxidized $\left[\mathrm{Ru}(\mathrm{bpy})_{3}\right]^{3+}$ further accepts electrons from the bis $(\mu$-oxo $)$ dicobalt sites and $\mathrm{Co} 2\left(\mathrm{CoN}_{3} \mathrm{O}\right)$ sites of MOC-1 to drive water oxidation ${ }^{1}$. The proof of Co oxidation of MOC-1 can be found in the cyclic voltammetry (CV) curves (Figure 3b), which was performed using a typical three-electrode cell in $0.2 \mathrm{M}$ borate buffer at $\mathrm{pH}$ 9.0. In this three-electrode cell, platinum wire acted as a counter electrode, while glassy carbon electrode and saturated 
calomel electrode (SCE) were employed as working electrode and reference electrode, respectively. The CV curve of MOC-1 showed two oxidation waves at $0.66 \mathrm{~V}$ and 1.32 $\mathrm{V}$ ( vs. SCE), which are attributed to $\mathrm{Co}^{\mathrm{III/II}}$ and $\mathrm{Co}^{\mathrm{IV} / \mathrm{III}}$ oxidation, respectively. In contrast, a minimum current was shown when a bare electrode was used in the same buffered solution. Similar oxidation waves have also appeared in MOC-2, MOC-3, and MOC-4 (Figures S20-22). 

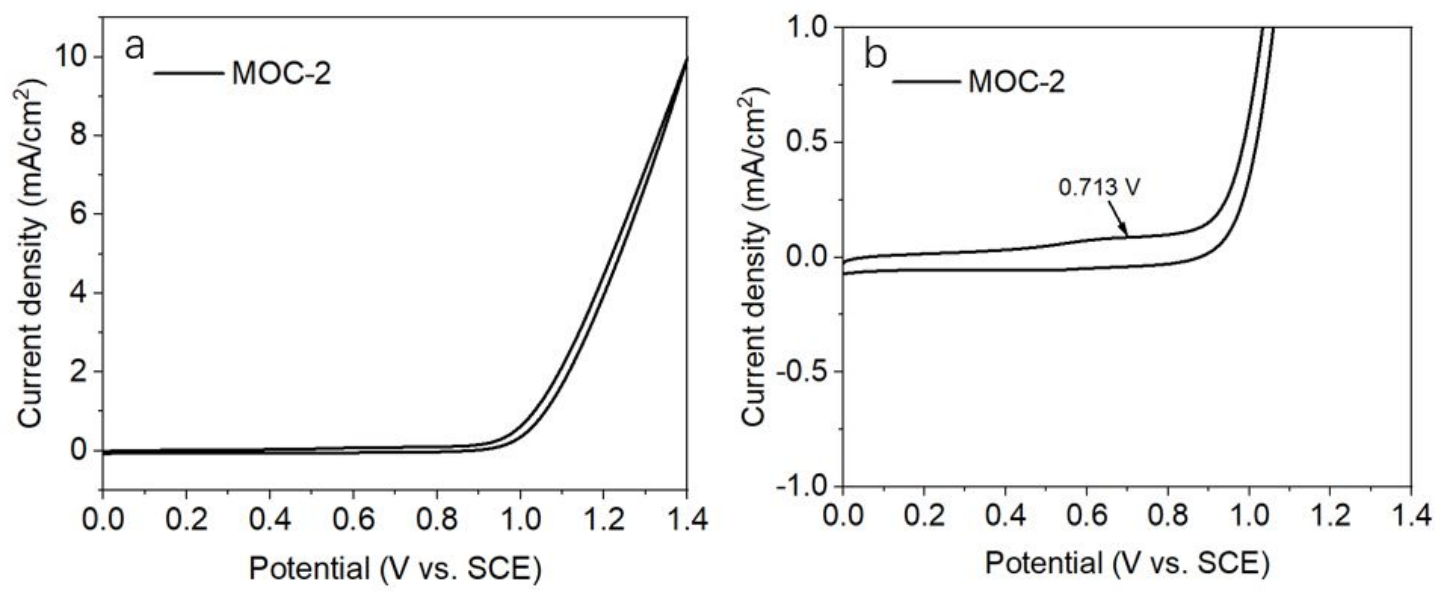

Figure S21. CV (a) and enlarged CV (b) curves of MOC-2 in $0.2 \mathrm{M}$ borate buffer (pH =9) (scan rate, $50 \mathrm{mV} / \mathrm{s})$.
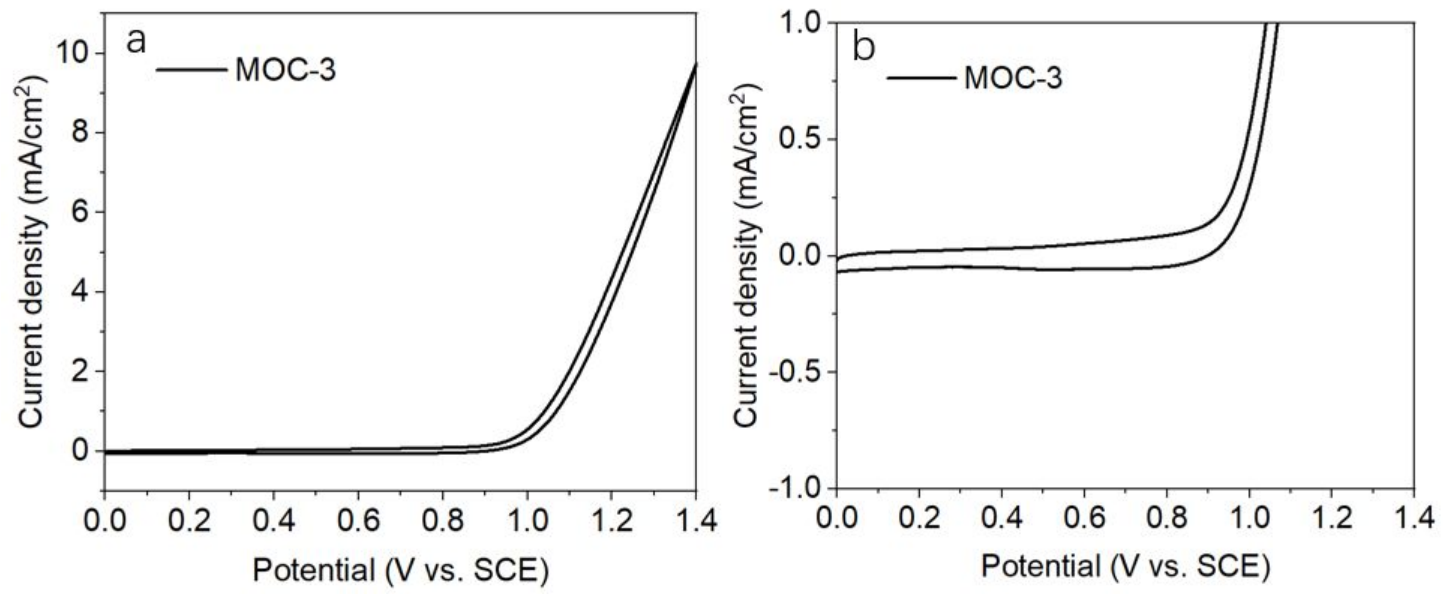

Figure S22. CV (a) and enlarged CV (b) curves of MOC-3 in $0.2 \mathrm{M}$ borate buffer (pH =9) (scan rate, $50 \mathrm{mV} / \mathrm{s})$. 

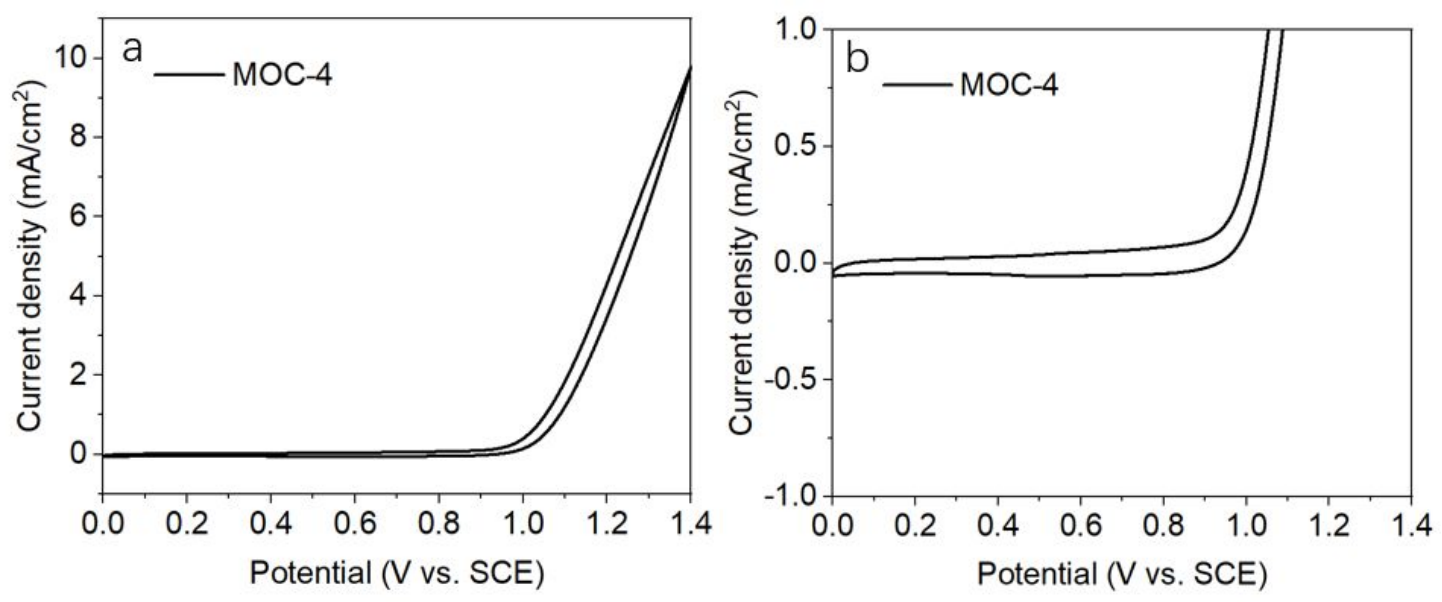

Figure S23. CV (a) and enlarged CV (b) curves of MOC-4 in $0.2 \mathrm{M}$ borate buffer (pH =9) $(\mathrm{scan}$ rate, $50 \mathrm{mV} / \mathrm{s})$.

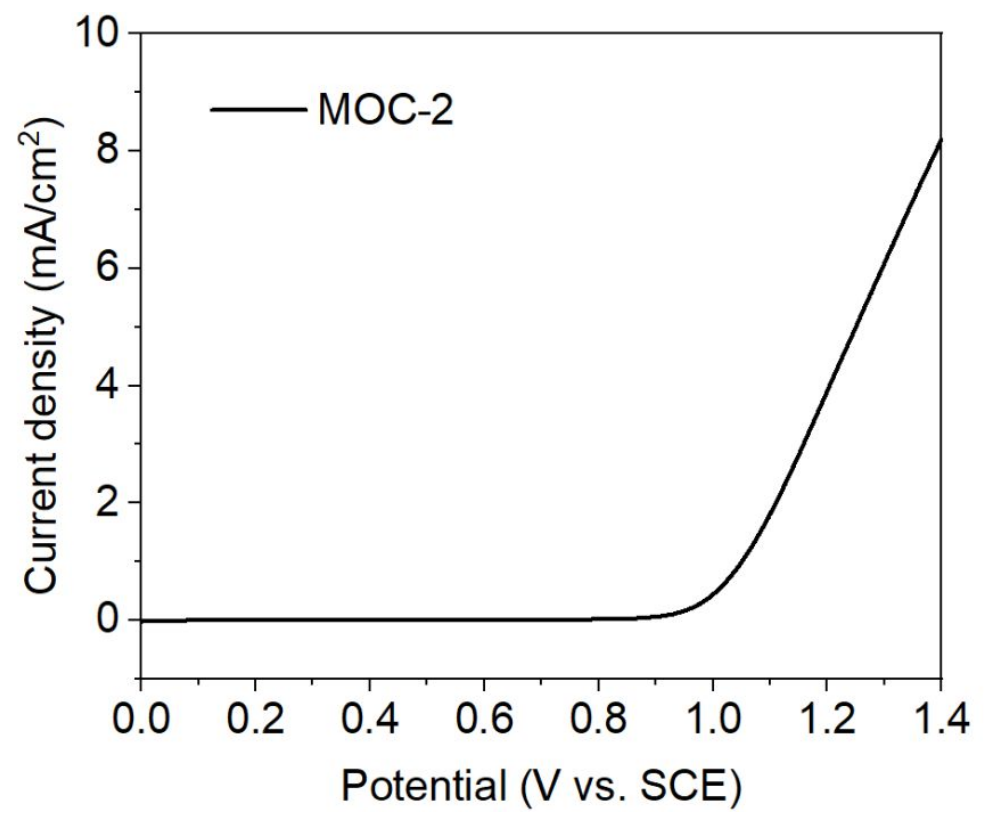

Figure S24. LSV curves of MOC-2 in $0.2 \mathrm{M}$ borate buffer $(\mathrm{pH}=9)($ scan rate, $5 \mathrm{mV} / \mathrm{s})$. 


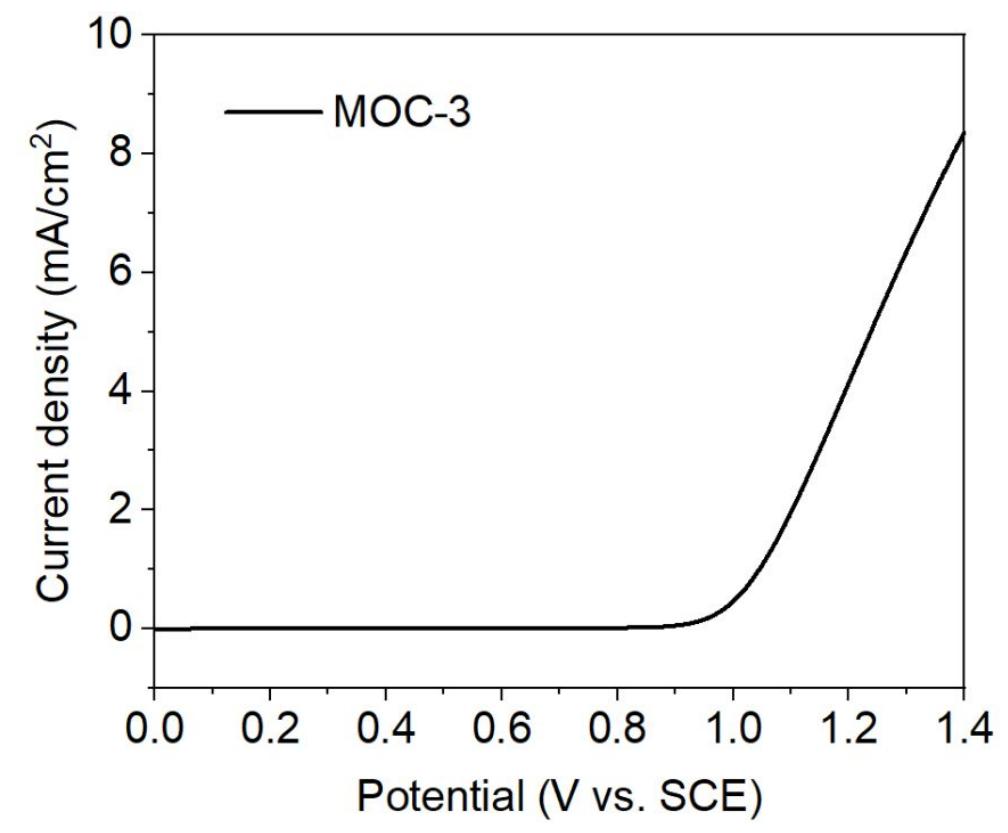

Figure S25. LSV curves of MOC-3 in $0.2 \mathrm{M}$ borate buffer $(\mathrm{pH}=9)(\mathrm{scan}$ rate, $5 \mathrm{mV} / \mathrm{s})$.

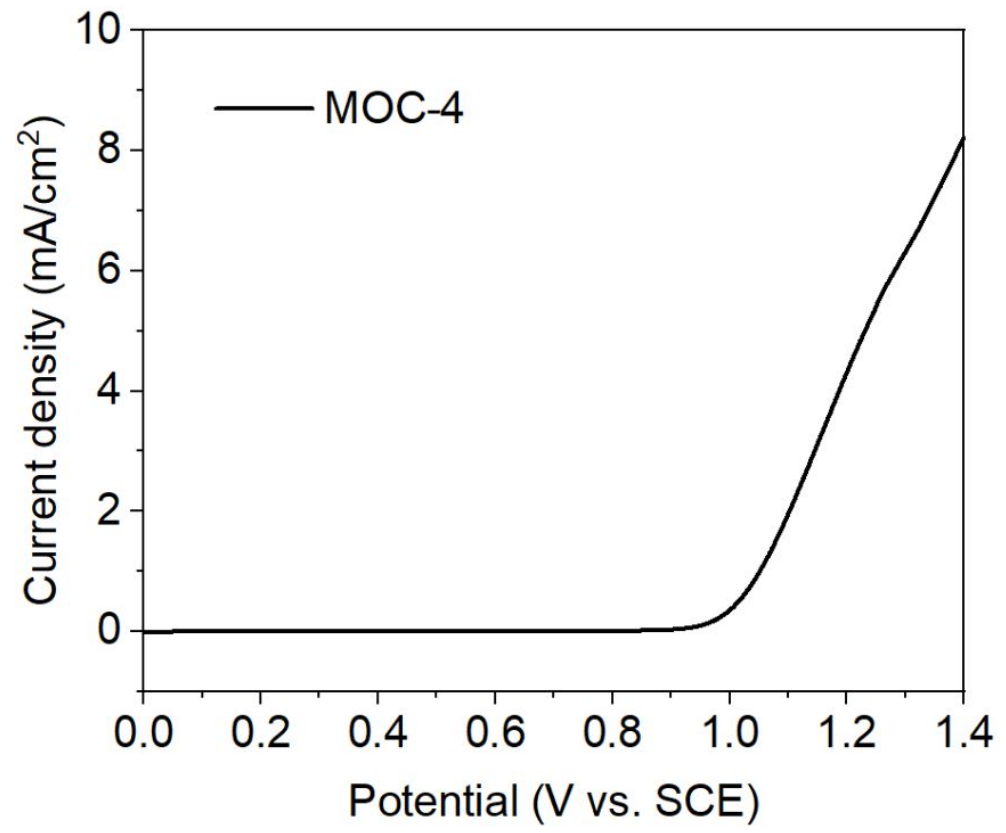

Figure S26. LSV curves of MOC-4 in $0.2 \mathrm{M}$ borate buffer $(\mathrm{pH}=9)($ scan rate, $5 \mathrm{mV} / \mathrm{s})$. 


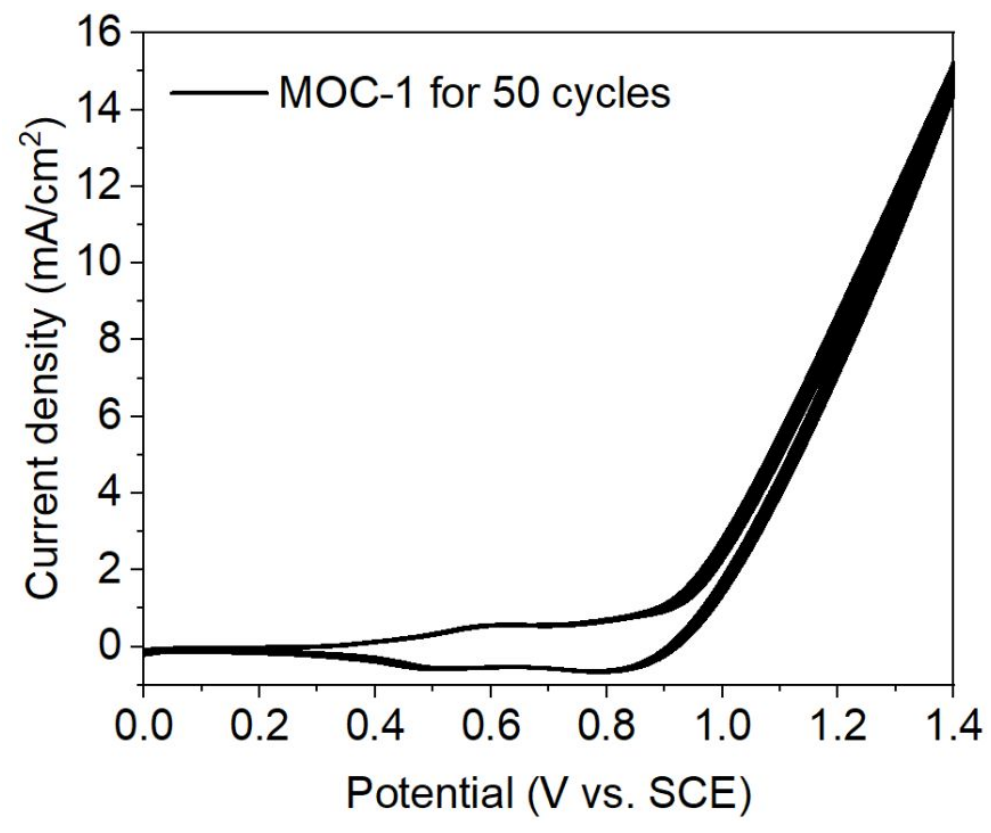

Figure S27. Multi-cycle CV curve of MOC-1 in $0.2 \mathrm{M}$ borate buffer $(\mathrm{pH}=9)$ (scan rate, $50 \mathrm{mV} / \mathrm{s}$ ) for 50 cycles.

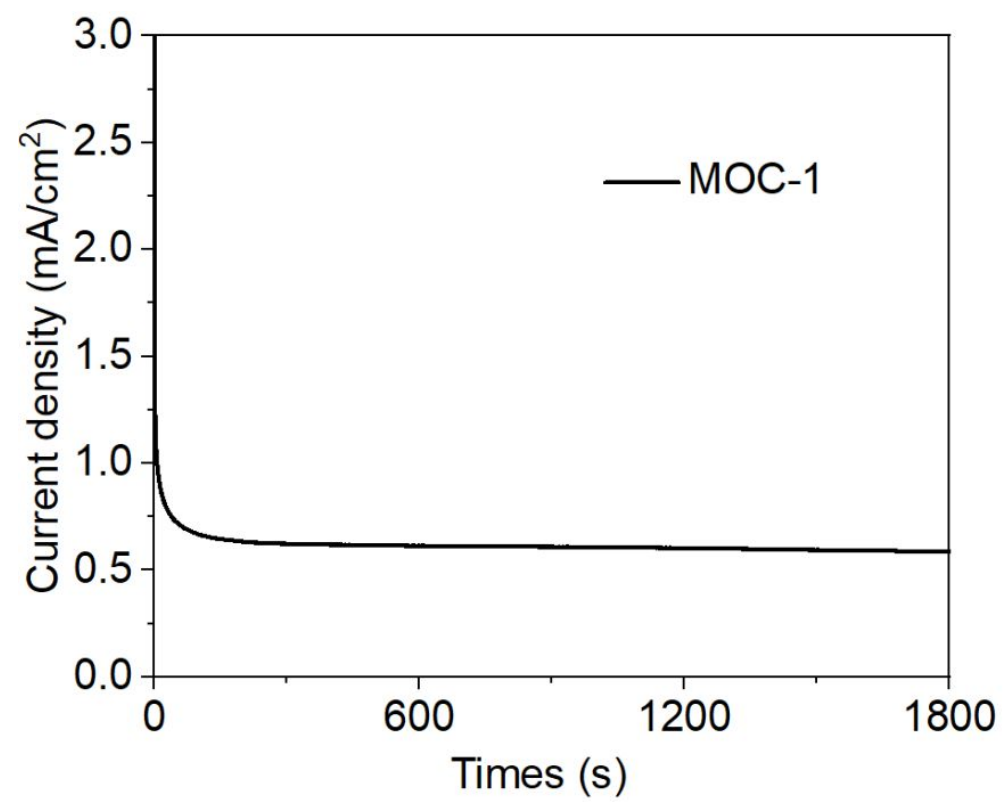

Figure S28. Chronoamperometric i-t curve was obtained with MOC-1 modified carbon paper electrodes. Electrolysis experiments were carried out in $0.2 \mathrm{M}$ borate buffer $(\mathrm{pH}$ $=9.0$ ) at a constant applied potential of $+0.9 \mathrm{~V}$ versus SCE. 


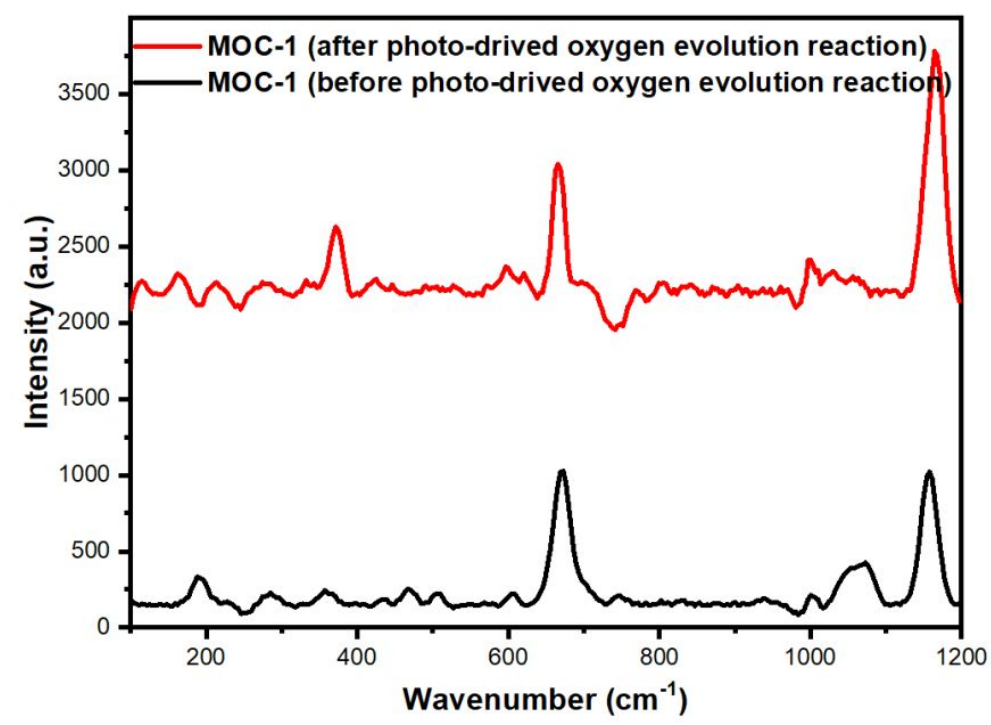

Figure S29. Raman spectra of MOC-1 before (black) and after (red) the photo-drived oxygen evolution reaction.

Raman spectroscopic analyses were carried out on a freshly prepared and a postcatalytic (used in the light-driven OER) MOC-1. Post-catalytic MOC-1 was recovered by collecting the solid material remaining in the irradiated three-component mixture by filtration, and subsequently washed with distilled $\mathrm{H}_{2} \mathrm{O}$ and acetone. Raman spectroscopic analysis is well suited to detect trace amounts of in-situ formed cobalt oxide $\left(\mathrm{CoO}_{x}\right)$ species due to the high surface sensitivity of this technique.

Comparison of the two spectra obtained (Figure S29) reveals that the highest intensity signals arising from MOC-1 at $669 \mathrm{~cm}^{-1}, 1000 \mathrm{~cm}^{-1}, 1066 \mathrm{~cm}^{-1}, 1158 \mathrm{~cm}^{-1}$ are present in both the freshly prepared and the post-OER photocatalytic samples. The signals at $1000 \mathrm{~cm}^{-1}, 1066 \mathrm{~cm}^{-1}, 1158 \mathrm{~cm}^{-1}$ might be attributed to the ligands, while the signal at $669 \mathrm{~cm}^{-1}$ to bis( $\mu$-oxo)dicobalt. The newly formed signal at $371 \mathrm{~cm}^{-1}$ might be ascribe to the residual photosensitizer adsorbed on MOC-1 after photo-drived OER. Crucially, no signals were observed in the Raman spectrum of the post-irradiated catalytic sample in the region $400-600 \mathrm{~cm}^{-1}$, which is the region in which $\mathrm{CoO}_{\mathrm{x}}$ species are typically highly vibrationally active in Raman spectroscopy. ${ }^{2}$ The absence of signals that could be assigned to $\mathrm{CoO}_{\mathrm{x}}$ species in the Raman spectrum of the recovered post-catalytic material strongly suggests that the observed OER activity arises directly from MOC-1 
which is a true molecular catalyst.

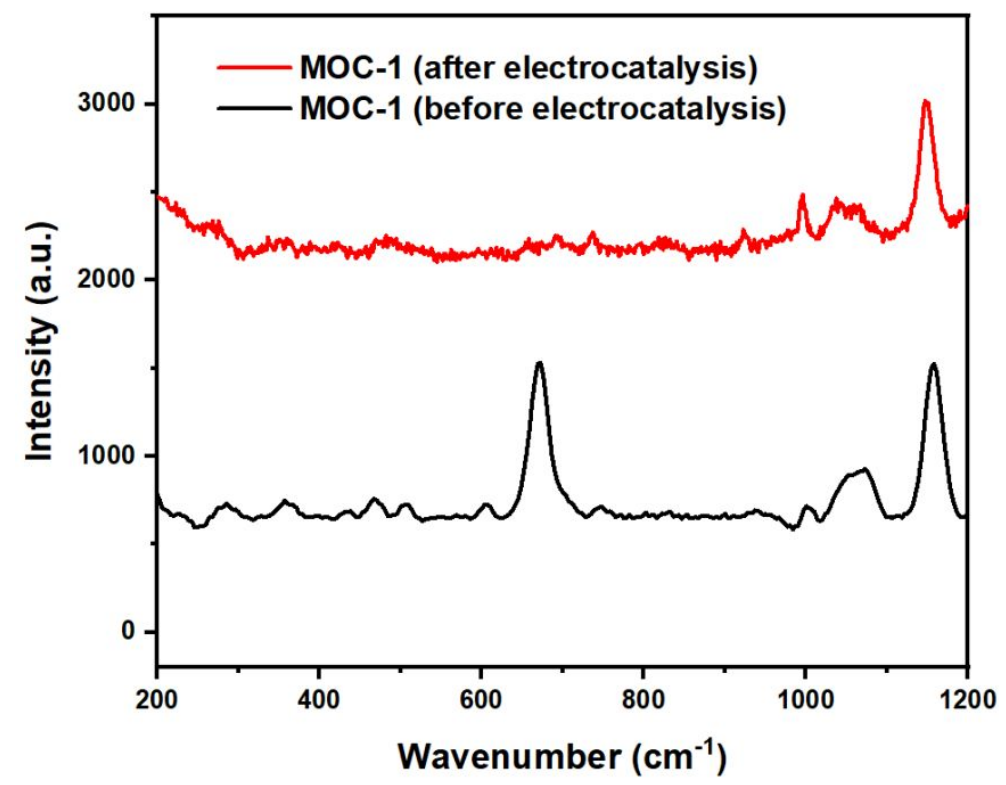

Figure S30. Raman spectra of MOC-1 before (black) and after (red) the electrocatalysis.

Comparison of the two spectra obtained (Figure S30) reveals that the highest intensity signals arising from MOC-1 at $1000 \mathrm{~cm}^{-1}, 1066 \mathrm{~cm}^{-1}, 1158 \mathrm{~cm}^{-1}$ are present in both the freshly prepared and the post-OER photocatalytic samples. The signals at $1000 \mathrm{~cm}^{-1}$, $1066 \mathrm{~cm}^{-1}, 1158 \mathrm{~cm}^{-1}$ might be attributed to the ligands. The disappeared signal at 669 $\mathrm{cm}^{-1}$ after the electrocatalysis might be caused by the oxidation of bis( $\mu$-oxo)dicobalt. Crucially, no signals were observed in the Raman spectrum of the post-irradiated catalytic sample in the region $400-600 \mathrm{~cm}^{-1}$, which is the region in which $\mathrm{CoO}_{\mathrm{x}}$ species are typically highly vibrationally active in Raman spectroscopy. ${ }^{2}$ The absence of signals that could be assigned to $\mathrm{CoO}_{\mathrm{x}}$ species in the Raman spectrum of the recovered postcatalytic material strongly suggests that the observed OER activity arises directly from MOC-1 which is a true molecular catalyst. 


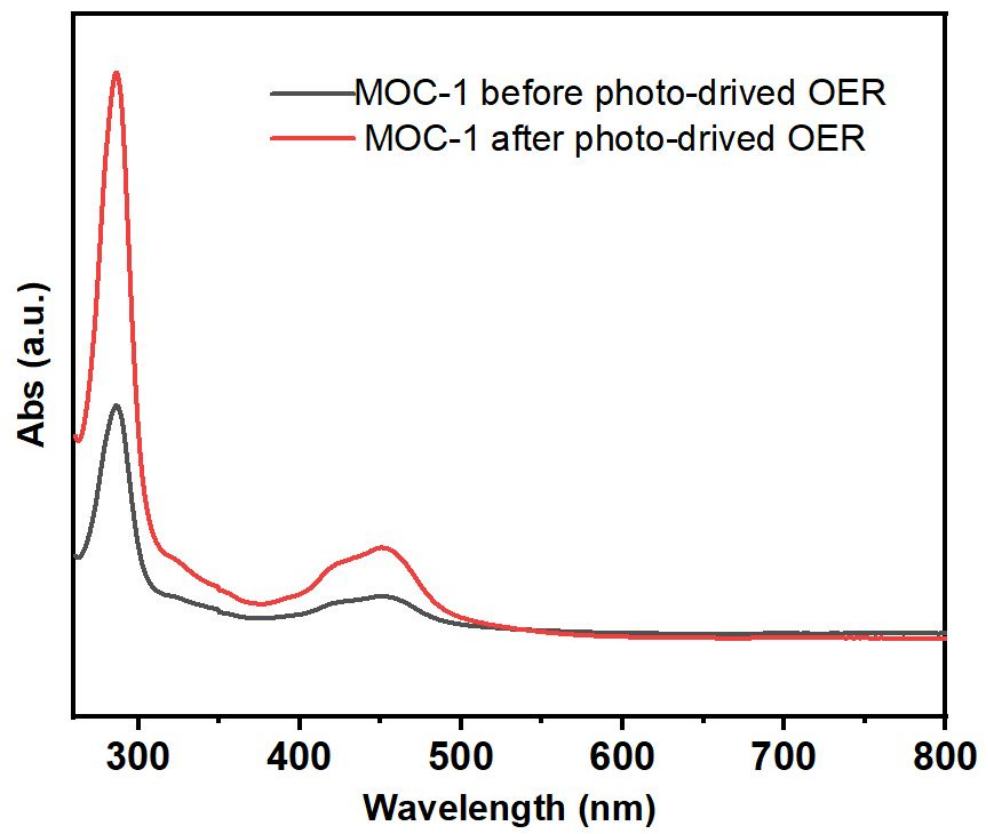

Figure S31. UV-Vis spectra of MOC-1 before (black) and after (red) photo-drived oxygen evolution reaction. The MOC-1 after photo-drived oxygen evolution reaction was obtained by collecting the solid material remaining in the irradiated threecomponent mixture by filtration, and subsequently washed with distilled $\mathrm{H}_{2} \mathrm{O}$ and acetone. 


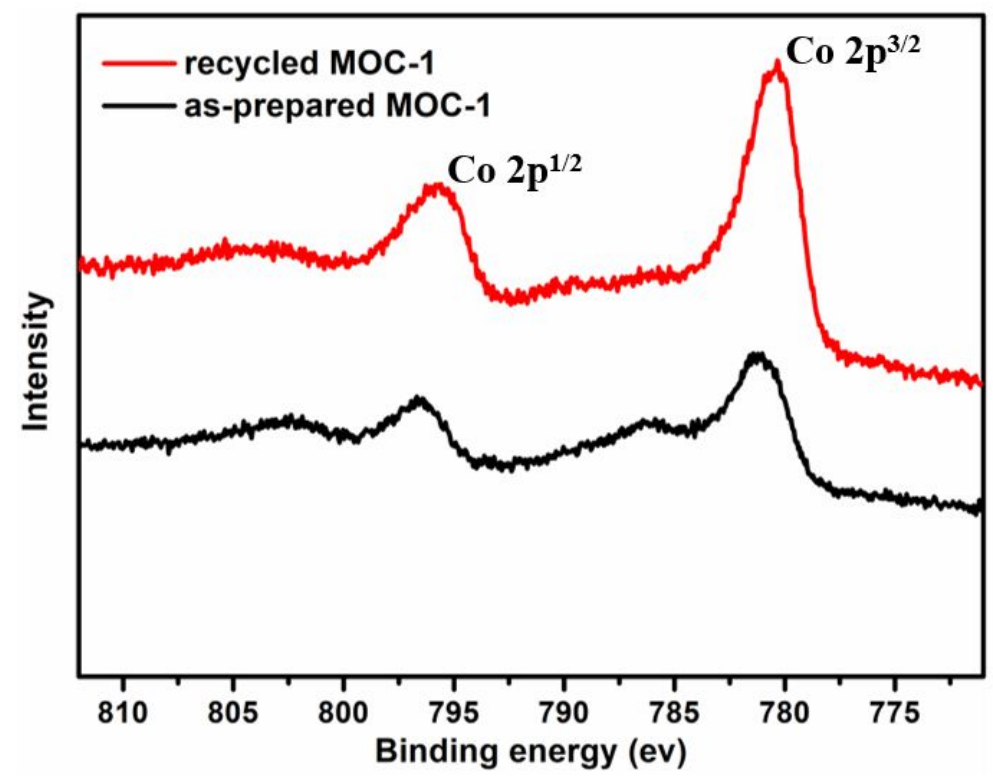

Figure S32. Co $2 p$ region of the XPS spectrum of MOC-1 before and after photoinduced reaction.

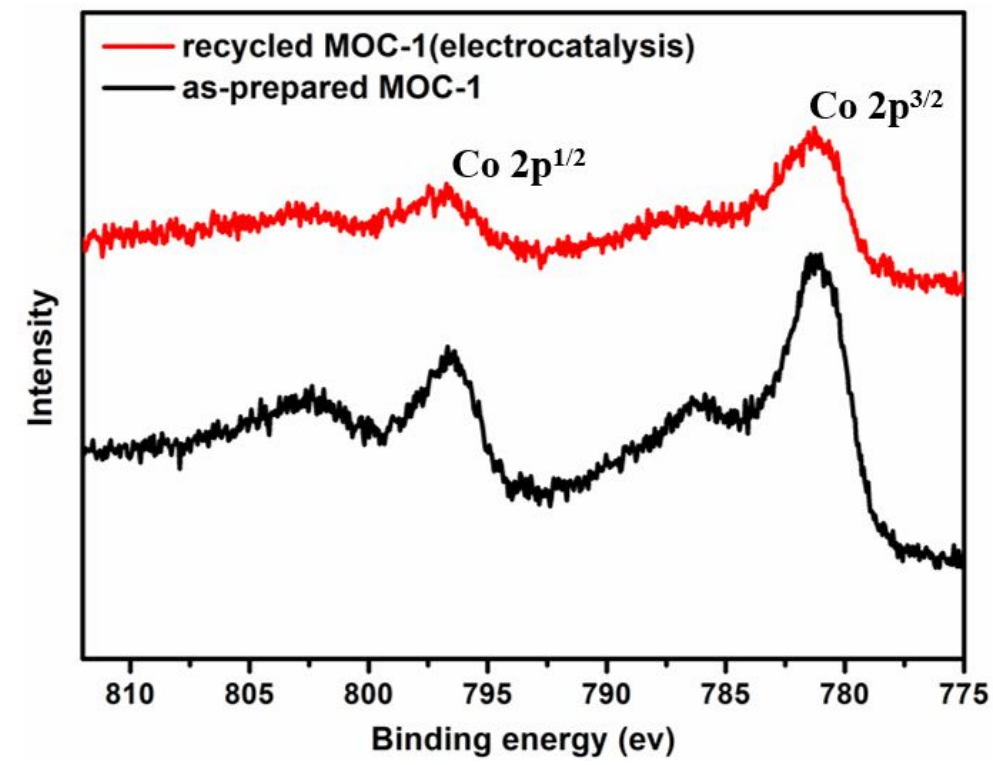

Figure S33. Co $2 p$ region of the XPS spectrum of MOC-1 before and after electrocatalysis. 
Table S3. Photo-induced water oxidation reaction under various reaction conditions.

\begin{tabular}{cccc}
\hline Catalysts & $\begin{array}{c}\text { Onset potential (V vs. } \\
\text { SCE) }\end{array}$ & Ep (V vs. SCE) $)^{\mathrm{b}}$ & $\begin{array}{c}\text { Over potential } \\
(\mathrm{mV})^{\mathrm{b}}\end{array}$ \\
\hline MOC-1 & 0.800 & 0.628 & 463 \\
MOC-2 & 0.927 & 0.71 & 592 \\
MOC-3 & 0.931 & -- & 587 \\
MOC-4 & 0.951 & -- & 593 \\
\hline
\end{tabular}

aThe onset potentials of water oxidation were obtained from the LSV curves at 0.1

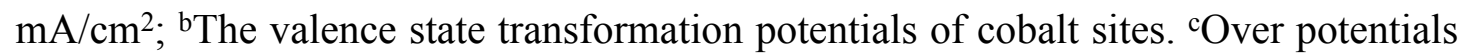
of water oxidation at $1 \mathrm{~mA} / \mathrm{cm}^{2}$.

Table S4. ICP-MS data for solution after photo-induced reaction. ${ }^{a}$

\begin{tabular}{|c|c|c|c|}
\hline Catalyst & $\begin{array}{l}\text { Reaction time } \\
\text { (min) }\end{array}$ & $\begin{array}{l}\text { Cobalt in reaction } \\
\text { solution after } \\
\text { centrifugation } \\
(\mathrm{ppm})\end{array}$ & $\begin{array}{l}\text { Cobalt species } \\
\text { dissolved in } \\
\text { reaction solution } \\
(\%)\end{array}$ \\
\hline MOC-1 & 60 & 3.74 & 1.85 \\
\hline
\end{tabular}


Table S5 Photo-induced water oxidation reaction under various reaction conditions. ${ }^{a}$

\begin{tabular}{|c|c|c|c|c|c|}
\hline Entry & Catalyst & $\begin{array}{c}\text { Light } \\
\text { wavelength }\end{array}$ & $\begin{array}{c}\text { Photosensitize } \\
\text { r }\end{array}$ & $\begin{array}{l}\text { Electron } \\
\text { scavenger }\end{array}$ & $\begin{array}{c}\text { Evolved } \mathrm{O}_{2} \\
{[\mu \mathrm{mol}]}\end{array}$ \\
\hline 1 & MOC-1 & $\begin{array}{c}\lambda=470 \mathrm{~nm} \\
(\mathrm{LED})\end{array}$ & {$\left[\mathrm{Ru}(\mathrm{bpy})_{3}\right] \mathrm{Cl}_{2}$} & $\mathrm{Na}_{2} \mathrm{~S}_{2} \mathrm{O}_{8}$ & 36.1 \\
\hline 2 & MOC-1 & None & {$\left[\mathrm{Ru}(\mathrm{bpy})_{3}\right] \mathrm{Cl}_{2}$} & $\mathrm{Na}_{2} \mathrm{~S}_{2} \mathrm{O}_{8}$ & Trace \\
\hline 3 & MOC-1 & $\begin{array}{c}\lambda=470 \mathrm{~nm} \\
(\mathrm{LED})\end{array}$ & None & $\mathrm{Na}_{2} \mathrm{~S}_{2} \mathrm{O}_{8}$ & Trace \\
\hline 4 & MOC-1 & $\begin{array}{c}\lambda=470 \mathrm{~nm} \\
(\mathrm{LED})\end{array}$ & {$\left[\mathrm{Ru}(\mathrm{bpy})_{3}\right] \mathrm{Cl}_{2}$} & None & Trace \\
\hline 5 & None & $\begin{array}{c}\lambda=470 \mathrm{~nm} \\
(\mathrm{LED})\end{array}$ & {$\left[\mathrm{Ru}(\mathrm{bpy})_{3}\right] \mathrm{Cl}_{2}$} & $\mathrm{Na}_{2} \mathrm{~S}_{2} \mathrm{O}_{8}$ & Trace \\
\hline
\end{tabular}

${ }^{\text {a }}$ Reaction conditions: photocatalysts $(2.0 \mathrm{mg}),\left[\mathrm{Ru}(\mathrm{bpy})_{3}\right] \mathrm{Cl}_{2}(50 \mu \mathrm{mol}), \mathrm{Na}_{2} \mathrm{~S}_{2} \mathrm{O}_{8}$ (400 $\mu \mathrm{mol}), 0.2 \mathrm{M}$ borate buffer $(10.0 \mathrm{~mL}$, initial $\mathrm{pH}=9.0)$, LED light $(\lambda=470 \mathrm{~nm})$, reaction for 1 hour. 
Table S6. The influence of photosensitizer and sacrificial agent on photocatalytic performance.

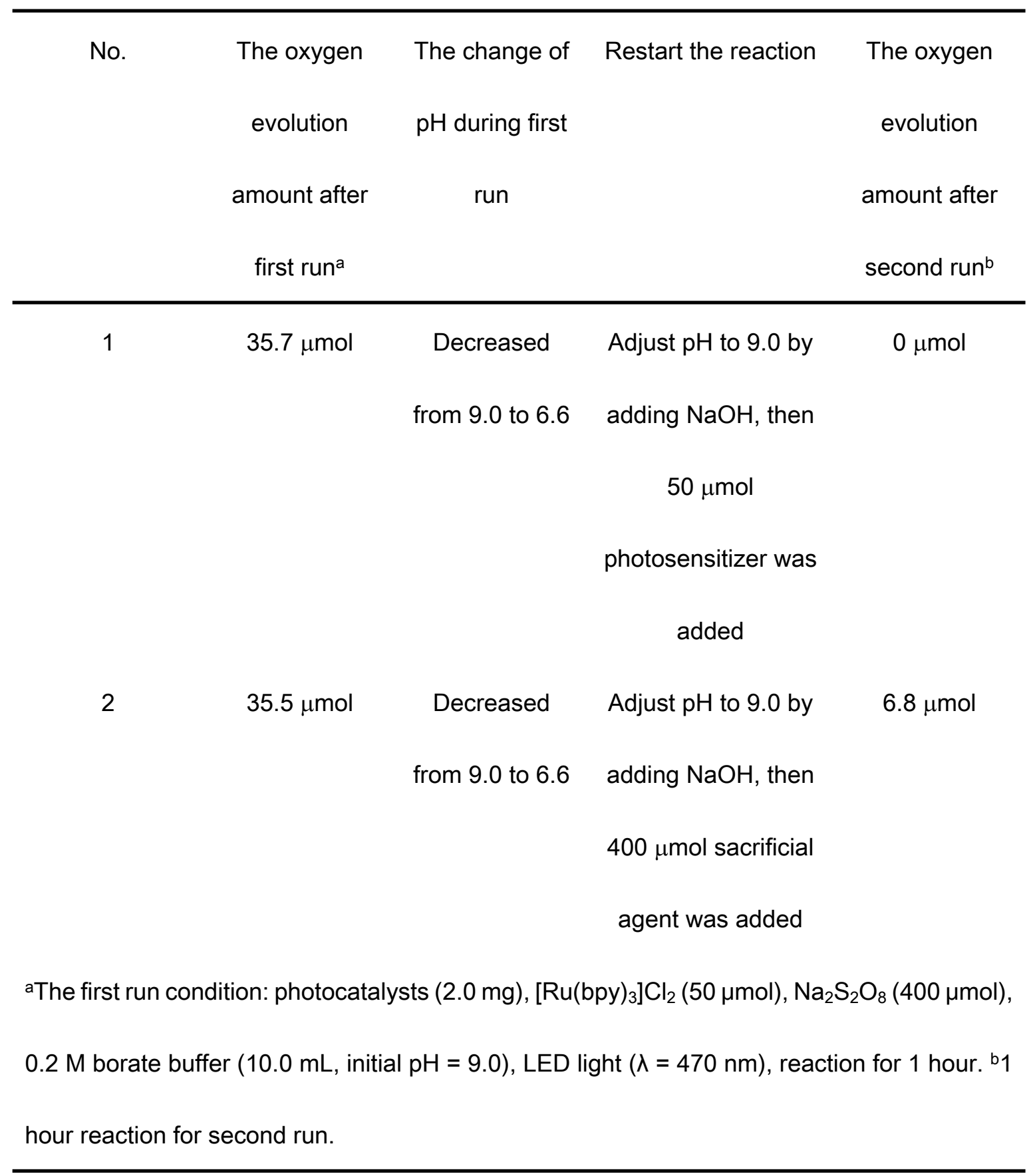


Table S7. Summary of TOFs of the reported water oxidation catalysts.

\begin{tabular}{|c|c|c|c|}
\hline Catalysts & $\begin{array}{c}\mathrm{O}_{2} \text { evolved } \\
\left(\mathrm{mmol} \cdot \mathrm{g}^{-1} \cdot \mathrm{h}^{-1}\right)\end{array}$ & $\operatorname{TOF}\left(\mathrm{s}^{-1}\right)$ & Ref. \\
\hline$\left[\mathrm{Ru}(\mathrm{bda}) \mathrm{L}_{2}\right]$ & 654.1 & 0.33 & 3 \\
\hline $\mathrm{P}_{2} \mathrm{~W}_{18} \mathrm{Co}_{4} @$ MOF-545 & 4.0 & $4.00 \times 10^{-2}$ & 4 \\
\hline $\mathrm{Co}_{3.9} / \mathrm{MIL}-101$ & $\sim$ & $1.20 \times 10^{-2}$ & 5 \\
\hline MOC-1 & 80.4 & $7.49 \times 10^{-3}$ & This work \\
\hline CoPOM/MIL-101 & 4.8 & $7.10 \times 10^{-3}$ & 6 \\
\hline MOC-2 & 40.8 & $4.78 \times 10^{-3}$ & This work \\
\hline h-Co@200 & 12.2 & $2.60 \times 10^{-3}$ & 7 \\
\hline MOC-3 & 20.0 & $2.40 \times 10^{-3}$ & This work \\
\hline $\mathrm{CW}-3$ & $\sim$ & $1.11 \times 10^{-3}$ & 8 \\
\hline $\mathrm{CoMn}_{2} \mathrm{O}_{4}$ & $\sim$ & $5.30 \times 10^{-4}$ & 9 \\
\hline $\mathrm{Co}_{3} \mathrm{O}_{4}$ nanocages & 8 & $3.20 \times 10^{-4}$ & 10 \\
\hline $\mathrm{Co}_{3} \mathrm{O}_{4} /$ mesoporous silica & 0.49 & $2.12 \times 10^{-4}$ & 11 \\
\hline $\mathrm{MnCo}_{2} \mathrm{O}_{4}$ & $\sim$ & $1.23 \times 10^{-4}$ & 9 \\
\hline Nano- $\mathrm{Fe}_{2} \mathrm{O}_{3}$ & 1.07 & $1.31 \times 10^{-5}$ & 12 \\
\hline Sonic- $-\mathrm{Fe}_{2} \mathrm{O}_{3}$ & 0.38 & $1.27 \times 10^{-5}$ & 12 \\
\hline Bulk- $\mathrm{Fe}_{2} \mathrm{O}_{3}$ & 0.25 & $5.67 \times 10^{-7}$ & 12 \\
\hline
\end{tabular}




\section{References}

(1) Song, Y.; Pi, Y.; Feng, X.; Ni, K.; Xu, Z.; Chen, J. S.; Li, Z.; Lin, W. Cerium-Based Metal-Organic Layers Catalyze Hydrogen Evolution Reaction through Dual Photoexcitation. J. Am. Chem. Soc. 2020, 142, 6866-6871.

(2) Ako, A. M.; Kathalikkattil, A. C.; Elliott, R.; Soriano-Lopez, J.; McKeogh, I. M.; Zubair, M.; Zhu, N.; Garcia-Melchor, M.; Kruger, P. E.; Schmitt, W. Synthetic Approaches to Metallo-Supramolecular Co(II) Polygons and Potential Use for H2O Oxidation. Inorg. Chem. 2020, 59, 14432-14438.

(3) Wang, L.; Duan, L.; Tong, L.; Sun, L. Visible light-driven water oxidation catalyzed by mononuclear ruthenium complexes. J. Catal. 2013, 306, 129-132.

(4) Paille, G.; Gomez-Mingot, M.; Roch-Marchal, C.; Lassalle-Kaiser, B.; Mialane, P.; Fontecave, M.; Mellot-Draznieks, C.; Dolbecq, A. A Fully Noble Metal-Free Photosystem Based on Cobalt-Polyoxometalates Immobilized in a Porphyrinic MetalOrganic Framework for Water Oxidation. J. Am. Chem. Soc. 2018, 140, 3613-3618.

(5) Liu, J.; Liu, Y.; Liu, N.; Han, Y.; Zhang, X.; Huang, H.; Lifshitz, Y.; Lee, S. T.; Zhong, J.; Kang, Z. Metal-free efficient photocatalyst for stable visible water splitting via a twoelectron pathway. Science 2015, 347, 970-974.

(6) Han, J.; Wang, D.; Du, Y.; Xi, S.; Chen, Z.; Yin, S.; Zhou, T.; Xu, R. Polyoxometalate immobilized in MIL-101(Cr) as an efficient catalyst for water oxidation. Appl. Catal. A: Gen. 2016, 521, 83-89.

(7) Zhao, J.; Zou, Y.; Zou, X.; Bai, T.; Liu, Y.; Gao, R.; Wang, D.; Li, G. D. Self-template construction of hollow $\mathrm{Co} 3 \mathrm{O} 4$ microspheres from porous ultrathin nanosheets and 
efficient noble metal-free water oxidation catalysts. Nanoscale 2014, 6, 7255-7262.

(8) Lan, Q.; Zhang, Z. M.; Qin, C.; Wang, X. L.; Li, Y. G.; Tan, H. Q.; Wang, E. B. Highly Dispersed Polyoxometalate-Doped Porous Co3 O4 Water Oxidation Photocatalysts Derived from POM@MOF Crystalline Materials. Chem. Eur. J. 2016, 22, 15513-15520.

(9) Menezes, P. W.; Indra, A.; Sahraie, N. R.; Bergmann, A.; Strasser, P.; Driess, M. Cobalt-manganese-based spinels as multifunctional materials that unify catalytic water oxidation and oxygen reduction reactions. ChemSusChem 2015, 8, 164-171.

(10) Wei, J.; Feng, Y.; Liu, Y.; Ding, Y. MxCo3-xO4 (M = Co, Mn, Fe) porous nanocages derived from metal-organic frameworks as efficient water oxidation catalysts. J. Mater. Chem. A 2015, 3, 22300-22310.

(11) Yusuf, S.; Jiao, F. Effect of the Support on the Photocatalytic Water Oxidation Activity of Cobalt Oxide Nanoclusters. ACS Catal. 2012, 2, 2753-2760.

(12) Townsend, T. K.; Sabio, E. M.; Browning, N. D.; Osterloh, F. E. Photocatalytic water oxidation with suspended alpha- $\mathrm{Fe} 2 \mathrm{O} 3$ particles-effects of nanoscaling. Energy Environ. Sci. 2011, 4, 4270. 